\title{
A LITERATURA NAS SOMBRAS AS EDIÇÕES EM PORTUGUÊS E OS TRADUTORES DA ATALĹ DE Chateaubriand na CRISE do Antigo Regime LUSO- BRASÍLICO (1810-1820)
}

http://dx.doi.org/10.11606/issn.2237-1184.v0i23p104-138

Pablo Iglesias Magalhães ${ }^{1}$

Universidade Federal do Oeste da Bahia
RESUMO:

Esse artigo discute a circulação de quatro edições em português da novela Atala (1801), impressas em Lisboa, Londres e Salvador (1810 1820), sendo a primeira proibida pelo Santo Ofício em 1812. Por meio de extensa pesquisa, foi possível localizar exemplares únicos e identificar os três anônimos tradutores da referida novela, revelando que aqueles personagens, ligados por amizade e pela maçonaria, atuaram contra $\mathrm{o}$ absolutismo e em prol dos projetos constitucionalistas nos dois lados do Atlântico.

\section{ABSTRACT:}

This paper discusses the circulation of four Portuguese editions of the novel Atala (1801), printed in Lisbon, London and Salvador (1810 1820), the first prohibited by the Santo Ofício in 1812. Through research, it was possible to find unique samples and identify the three anonymous translators of that novel, revealing that those characters, linked to friendship and freemasonry, acted against absolutism and proconstitutionalists projects on both sides of the Atlantic.
PALAVRAS-CHAVE:

Literatura colonial.

Traduções portuguesas.

Santo Ofício.

Censura.

Maçonaria.

Hipólito da Costa.

KEYWORDS:

Colonial literature.

Portuguese translations.

Santo Ofício.

Censorship.

Masonry.

Hipólito da Costa.

\footnotetext{
${ }^{1}$ Professor Adjunto II de História do Brasil I e História Ibérica na Universidade Federal do Oeste da Bahia.
} 


\section{— A origem da Atala (1801)}

Paris, abril de 1801 (germinal, An IX). Naquele ano foi impressa a novela Atala, ou Les Amours de Deux Sauvages dans le désert, de François René Auguste de Chateaubriand (Saint-Malo, 4 de Setembro de 1768 - Paris, 4 de Julho de 1848), também conhecido como visconde de Chateaubriand. A Atala foi, originalmente, um episódio de Génie du Christianisme, e tornou-se um best-seller, alcançando cinco edições no mesmo ano em que foi publicado. $\mathrm{O}$ Génie du Christianisme, além da Atala, continha a novela René (1802), que foram publicadas separadamente, mas ambas eram protagonizadas por indígenas que habitavam a América do Norte. Em 1821, a novela Les Natchez, até então inédita, contando uma versão da história do povo indígena que se rebelou contra os franceses em 1727, foi incorporada às Euvres complètes de Chateaubriand. A Atala, bem como seus demais escritos, consagrou-o como um dos autores mais lidos na Europa nas primeiras décadas do século XIX.

A biografia de Chateaubriand é bastante conhecida, apesar de ainda conservar alguns elementos obscuros. Nascido no seio da aristocracia francesa em Saint-Malo, a 4 de Setembro de 1768, aos 18 anos se tornou sub-tenente do Exército francês. Logo em seguida teve início a Revolução Francesa, que teve impacto significativo na vida de Chateaubriand. Ele próprio revelou, na primeira edição francesa da Atala, os pormenores da sua biografia que o levaram a escrever a novela:

Eu era ainda muito moço quando concebi a ideia de escrever a epopeia do homem da natureza, ou de pintar os costumes dos selvagens, ligando-os a qualquer acontecimento conhecido. Afora a descoberta da América, nenhum assunto me pareceu tão importante, sobretudo para os franceses, como a terrível matança dos Natchez, na Luisiana em 1727. A conspiração de todas as tribos índias para libertar o Novo Mundo duma escravidão de 
dois séculos, figurou-se-me quase tão feliz assunto como a conquista do México. Tracei alguns fragmentos desta obra, mas conheci desde logo que me faltavam as verdadeiras cores, e que, para tornar fidelíssimo o quadro, precisava de seguir o exemplo de Homero, visitando os povos cujos costumes queria descrever. ${ }^{2}$

O novelista revelou também que, pouco mais de dez anos após a Independência dos EUA, foi seduzido pela história de uma reunião de povos indígenas, ocorrida ainda na primeira metade do século XVIII, para lutar contra o domínio colonial europeu na América do Norte. No mesmo ano em que eclodiu a Revolução Francesa, Chateaubriand seguiu para América, influenciado pelos relatos de viagem de James Cook, com o objetivo de buscar uma passagem marítima que ligasse o Atlântico e o Pacífico pelo hemisfério setentrional. $\mathrm{O}$ objetivo primordial da viagem não teve efeito, contudo, dali nasceu sua Atala, inspirada (e romantizada) nos povos indígenas norte-americanos:

Em 1789 comuniquei ao sr. de Malesherbes o projeto que formava de me transportar à América. Todavia, para dar à minha viagem um fim útil, planejei descobrir por terra a tão procurada passagem, acerca da qual o próprio Cook deixara dúvidas. Parti, percorri as solidões americanas, e voltei com projetos da nova viagem, a qual devia prolongar-se por nove anos. Era meu intento atravessar todo o continente da América setentrional, subir ao longo das praias, pelo norte da Califórnia, e volver pela baía de Hudson, ladeando o polo. O sr. de Malesherbes incumbiu-se de dar conta ao governo destes planos, e foi então que lhe li os fragmentos da pequena obra, que hoje publico. Veio a Revolução e destruiu-me todos os projetos. Banhado no sangue de meu único irmão, de minha cunhada e de seu nobilíssimo pai, tendo visto morrer minha mãe e minha talentosa irmã em resultado de maus tratos que lhes infligiram nos cárceres, eu vagueei por terras estrangeiras, onde o único amigo que me restava se apunhalou nos meus braços. [...] A Atala foi escrita no deserto, à sombra das barracas dos selvagens. Não sei se o público apreciará essa história, que sai de todos os caminhos traçados e que vem mostrar-lhe usos e paisagens inteiramente desconhecidos na Europa. ${ }^{3}$

Sucesso prodigioso na Europa, Atala fora traduzido em quase todos os idiomas europeus, com exceção das línguas eslavas e escandinavas. Ainda em 1801 foi traduzido para o alemão e impresso em Dresden. A aceitação pelos

\footnotetext{
${ }^{2}$ CHATEAUBRIAND, François-Auguste. Atala, ou les amours deux sauvages dans le desert. Paris: Chez Migneret, Imprimeur , rue Jacob, N. ${ }^{\circ}$ 1186; Et à l'ancienne Librairie de Dupont, rue de la Loi , N. ${ }^{\circ} 228$, AN IX . (1801.), pp. IX. Tradução nossa feita sobre a primeira edição.

${ }^{3}$ CHATEAUBRIAND, Op. Cit., 1801, p. X. Uma excelente biografia de Chateaubriand, inserindo-o no seu contexto histórico, ver: FUMAROLI, Marc. Chateaubriand: poèsie et terreur. Paris: Gallimard, 2003. Também a introdução de BERCHET, Jean-Claude (ed). Atala, René, Les Natchez. Paris: Le Livre de Poche, 1989.
} 
leitores foi tão grande que gerou a paródia Alala ou les Habitans du Desert, Parodie D'Atala, Au Grand Village (1801).

A novela Atala logo despertou o interesse dos jovens intelectuais lusófonos, não tardando para que surgissem traduções na língua portuguesa. Em nenhuma dessas traduções, contudo, o prefácio acima, com suas referências a Voltaire, então mal visto pelas autoridades censoras de Portugal, e sublevações contra o domínio colonial europeu na América foi republicado. Os tradutores o omitiram para, decerto, não chamar mais a atenção da censura.

As traduções portuguesas, contudo, são objeto de imensa confusão, tanto por parte dos historiadores da literatura quanto dos historiadores do livro em Portugal e no Brasil. $O$ presente artigo tem como objetivo identificar corretamente, pela primeira vez, as diferentes edições portuguesas da Atala de Chateaubriand. Essas edições, com pelo menos três traduções variantes, foram impressas nos anos de 1810 (Lisboa, com segunda edição em 1820), 1818 (Paris e Londres) e 1819 (Salvador). Não há dúvidas que se trata de um livro que influenciou profundamente a literatura e a estética do romantismo em Portugal e no Brasil, não se restringindo ao limitado círculo acadêmico, mas alcançando até mesmo homens e mulheres pouco instruídos. Brito Broca observou que

O interesse despertado por Lamartine, Vigny, Musset e outras das grandes figuras do Romantismo francês, não devia restringir-se ao círculo de intelectuais, mas estender-se ao grande público, dado o fato de ter-se procurado divulgar, bem cedo, algumas obras desses autores em português. Já em 1819, na Bahia, dos prelos de Manuel Antônio da Silva Serva saía uma edição de Atala ou Os Amores de Dois Selvagens no Deserto, traduzido na linguagem portuguesa por ...***.5

O objetivo da presente investigação consiste em revelar os aspectos históricos e bibliográficos das diferentes edições e traduções, identificando seus anônimos tradutores, com destaque para a edição da Atalá ou os dois amores no deserto impressa em 1819 na Tipografia de Manoel Antonio da Silva Serva, a primeira novela que se publicou na Capitania da Bahia. Esse livro inspiraria, nas quatro décadas seguintes, as gerações de autores do romantismo no Brasil. No dizer de Joaquim Nabuco:

\footnotetext{
${ }^{4}$ SABIN, Joseph. Biblioteca Americana: A Dictionary of Books Relating to America from its discovery to the present time by Joseph Sabin. New York, J. Sabin \& Sons, 84, Nassau Street, 1870, Vol. III, pp. 536-540.

${ }^{5}$ BROCA, Brito. Românticos, pré-românticos, ultra-românticos: vidada literária e romantismo brasileiro. Rio de Janeiro: Polis, 1979. p. 101
}

107| ENSAIOS 
Todos sabem que no princípio do século Chateaubriand fundou uma poesia nova, e que essa poesia saiu das florestas americanas. 'Atala' e os 'Natchez', que encerravam-na, impressionaram o Sr. J[osé]. de Alencar, quando já eram apenas monumentos em ruínas [...]. A impressão foi por tal modo forte que, ainda hoje, os índios do escritor brasileiro pensam, amam e falam como se fossem amigos de René. ${ }^{6}$

Antes, porém, de influenciar toda uma geração de literatos brasileiros, particularmente os indigenistas românticos, as traduções da Atala percorreram caminhos tortuosos, sendo, inclusive, proibida pelos censores portugueses em 1812.

\section{As traduções portuguesas da Atala}

Os registros bibliográficos acerca das edições e traduções portuguesas da Atala são, até o presente, bastante confusos. Os elementos históricos que envolvem os livros e os homens que os traduziram são, o que é mais grave, completamente ignorados. Os principais aspectos e as diferenças literárias das duas traduções da Atala são, não obstante, conhecidos por diligência e mérito do professor Thierry Proença dos Santos, que desenvolveu notáveis estudos acerca da referida novela..$^{7^{3}}$ Em sua pesquisa, todavia, não lhe foi possível examinar nenhum exemplar da primeira edição de 1810, censurada em 1812. Também não encontrou nenhum exemplar da tradução portuguesa da Atala impressa em Londres, em 1818, e não tivera, sequer, notícia da existência da edição feita naquele mesmo ano em Paris.

\footnotetext{
${ }^{6}$ NABUCO, Joaquim. “Aos Domingos II". A Polémica Alencar - Nabuco, apresentação Afrânio Coutinho, Rio de Janeiro. Brasília: Ed. da Universidade de Brasília, 1978, p. 84.

${ }^{7}$ SANTOS Thierry Proença dos. Atala Traduzida - Estudo das Primeiras Versões Portuguesas. Dissertação de mestrado em Linguística. Faculdade de Letras - Universidade de Lisboa. Lisboa, 1999. 242 fl. ; SANTOS, Thierry Proença dos. "Atala traduzida em tempos de censura - para um estudo da recepção e da manipulação das versões portuguesas do romance de Chateaubriand". Actas do IV Congresso Internacional de Literatura Comparada "Estudos Literários / Estudos Culturais". Évora: Universidade de Évora, 2004; SANTOS. "Variação, reescrita, retradução - estudo comparativo de versões portuguesas e brasileiras de Atala de Chateaubriand (II)". CORREIA, Clara Nunes; GONÇALVES, Anabela (org.). Actas do XVI Encontro Nacional da Associação Portuguesa de Linguística (Coimbra, 28 a 30 de Setembro de 2000). Lisboa: Associação Portuguesa de Linguística, 2001, pp. 469-480 ; SANTOS. "As primeiras versões de Atala de Chateaubriand em Portugal e no Brasil ou a inevitável colocação cultural no tecido linguístico e discursivo". Livro de Comunicações do Colóquio Internacional: Caminhos do Mar / Ocean Paths. Funchal: Departamento de Cultura da Câmara Municipal Funchal, 2001, pp. 207-223. Sou grato ao professor Thierry Proença dos Santos que, a meu pedido, gentilmente, disponibilizou a sua dissertação e os artigos aqui indicados.
} 


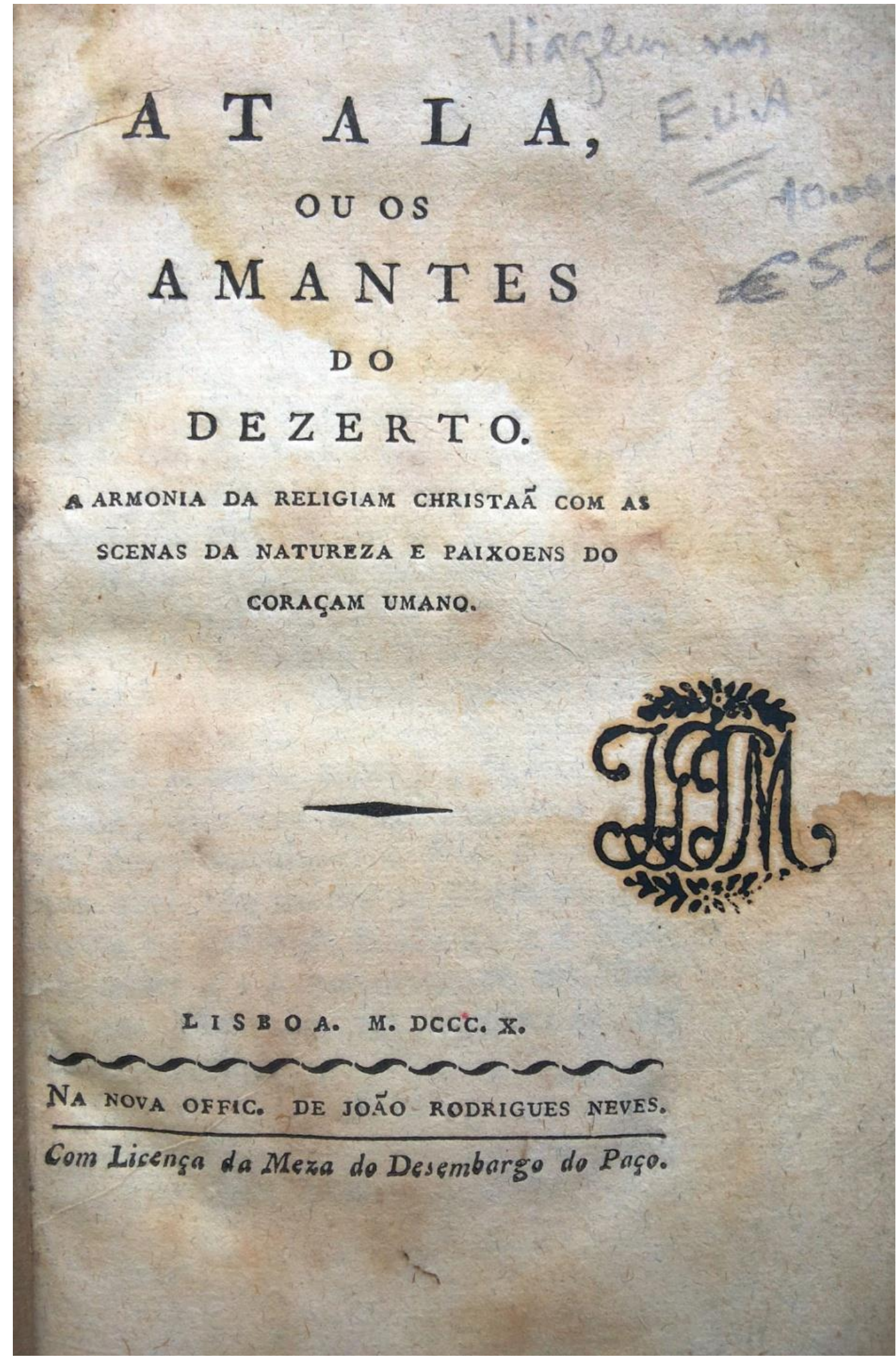

Frontispício da edição de 1810. Coleçãa do Autor 
Nas suas investigações, durante o mestrado em linguística pela Universidade de Lisboa e em artigos posteriores, o estudioso das traduções portuguesas da Atala só pôde examinar os exemplares da Bahia (1819) e Lisboa (1820), bem como o manuscrito que foi usado para a impressão da edição de 1810, conservado na Torre do Tombo. Apesar de não ter localizado todas as traduções primitivas da Atala, os estudos de Thierry Santos tiveram o inegável mérito de analisar, comparar e revelar os estilos linguísticos e as particularidades literárias daquelas duas traduções, então identificadas por ele, além de discutir as questões relativas à censura da edição de 1810. Apesar do notável esforço do professor Santos em investigar com rigor as edições da Atala, as pesquisas acadêmicas que seguiram às suas mantiveram as confusões em relação tanto às edições quanto às traduções, asseverando até mesmo a existência de uma edição na Bahia, de 1810, que nunca chegou a ser realizada, até porque a impressa só foi estabelecida naquela capitania em $1811^{8}$

O aprofundamento das pesquisas possibilitou, no presente estudo, identificar e localizar dois exemplares da primeira edição portuguesa da Atala, datados de 1810, sendo um deles conservado na Biblioteca Nacional do Rio de Janeiro e o segundo pertencente a coleção particular do autor. Impresso na Oficina de João Rodrigues Neves, os exemplares dessa edição tornaram-se de suma raridade, não sendo encontrado nem mesmo na Biblioteca Nacional de Portugal. A razão disso reside, provavelmente, no fato de a tradução primitiva de Atala ter sido proibida em 1812 pela Real Mesa Censória.

Também foi localizado um exemplar da edição de Londres, que será discutido mais adiante. Até o presente não foi possível encontrar para exame nenhum exemplar da tradução impressa em Paris em 1818. Sabemos da sua existência pelo anúncio num Catálogo parisiense de livros portugueses: "Atala, ou os Amores de dous Salvagens (sic) no deserto, pelo Visconde de Chateaubriand. Paris, 1818. 1 vol. em 18. 3fr." "Ela foi certamente impressa na oficina de Antoine Bobée. Naquele mesmo ano, 1818, e na mesma oficina de Bobée foi impressa outra obra de Chateaubriand, Renato e as Aventuras de Aristonoo, traduzidas em Português por Bento Luis Vianna (Filinto Insulano), que contou com o auxílio de Francisco Manoel do Nascimento (Filinto Elysio) para remover os "bastardos gellecismos" da sua tradução. No "Aviso ao Leitor"

\footnotetext{
${ }^{8}$ MELLO, Melissa Moura. Atala de F.-R. de Chateaubriand: objet fictionnel pour une pédagogie chrétienne.Orientador Gil, Beatriz Cerisara. Universidade Federal do Rio Grande do Sul. Instituto de Letras. Programa de Pós-Graduação em Letras. 2013 , p. 136.

${ }^{9}$ BASTOS, José Timóteo da Silva Bastos. História da Censura Intelectual em Portugal: (ensaio sobre a compressão do pensamento

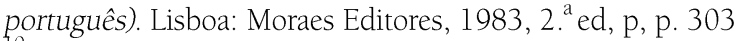

${ }^{10}$ Catalogo de Livros Portuguezes: obras novas. Paris: Officina de J. Smith, rua Montmorency, n16,[1827] p. 1
} 
ele previne seus interlocutores que preparava outras traduções. Teria alguma relação com a tradução parisiense da Atala? Somente encontrando um exemplar para exame isso poderá ser respondido.

Há a notícia equivocada da existência de uma edição lisboeta datada de 1818, indicada no Catálogo do Gabinete Português de Leitura do Rio de Janeiro, que, na realidade, a confundiu com a edição de Londres, custodiada naquela instituição. ${ }^{11}$ Não existe, com toda certeza, edição lisboeta de 1818. Certo é a existência de uma edição de Lisboa em 1820, reimpressão realizada vis a vis da edição de 1810, ambas com 157 páginas, mas com as diferenças de muitas atualizações ortográficas. Enquanto o papel de linho utilizado na edição de 1810 é mais espesso e de melhor qualidade, o apuro tipográfico da edição de 1820 é muito superior, pois feita na Impressão Régia. Em apenas oito anos, o livro saiu da condição de proibido para ganhar prelo na oficina tipográfica responsável por publicar os documentos oficiais do governo português. Assim, é possível, ainda que não comprovado, que a edição de 1820 tenha sido impressa após a Revolução Liberal e Constitucional do Porto, iniciada a 24 de agosto de 1820, incidindo no afrouxamento da censura. Entre fins de 1820 e 1822, diversos autores cujo os escritos eram proibidos circular em Portugal, à exemplo de Voltaire e Volney, passaram a ser traduzidos e impressos. ${ }^{12}$

Desde o século XIX que os bibliógrafos portugueses, à exemplo de Inocêncio Francisco da Silva, reconhecem Filippe Ferreira de Araújo e Castro (1771 - 1849), bacharel em Leis pela Universidade de Coimbra (1794) e juiz de fora da Vila de Abrantes (1796), como o verdadeiro tradutor da Atala. É possível, apesar desse reconhecimento do lídimo tradutor, afirmar que o autor do Diccionario Bibliographico Portuguez sequer viu algum exemplar da Atala, nem na sua edição de 1810 e nem na de 1820, visto que ele demonstra dúvidas de quando teria sido impressa. ${ }^{13}$ É possível, pela primeira vez, estabelecer um quadro das traduções da Atala na língua portuguesa entre 1810 e 1820:

\footnotetext{
${ }^{11}$ Real Gabinete Português de Leitura. Catalogo dos livros do Gabinete Portuguez de Leitura no Rio de Janeiro. Rio de Janeiro : Typ. Commercial de F. de O.Q. Regadas, 1858, p.2 41.

${ }^{12}$ Sobre as traduções da obra de Voltaire ver: IGLESIAS MAGALHÃES, P. A. "O Tradutor dos Abomináveis Princípios: José Pedro de Azevedo Sousa da Câmara e a circulação dos escritos de Voltaire em Portugal e no Brasil (1790-1834)". Historia (UNESP. Assis), v. 35, p. 22, 2016. < http://dx.doi.org/10.1590/1980-436920160000000101 > . Acesso em: 16 de maio de 2017.

${ }^{13}$ SILVA, Inocêncio Francisco da Silva. Diccionario Bibliographico Portuguez. Lisboa: Imprensa Nacional, 1860, T. II, p. 296 e 297
} 


\section{Quadro bibliográfico das traduções da Atala (1810-1820)}

\begin{tabular}{|c|c|c|}
\hline Dados Bibliográficos & Atribuição de tradução & Localização dos Exemplares \\
\hline $\begin{array}{l}\text { ATALA, // OU OS // AMANTES // DO // } \\
\text { DEZERTO. // A ARMONIA DA RELIGIAM } \\
\text { CHRISTAÃ COM AS // SCENAS DA } \\
\text { NATUREZA E PAIXOENS DO // } \\
\text { CORAÇAM UMANO // // LISBOA. M. } \\
\text { DCCC. X. // NA NOVA OFFIC. DE JOÃO } \\
\text { RODRIGUES NEVES. // // Com Licença da } \\
\text { Mesa do Desembargo do Paço. } 157 \text { p. } 14,5 \\
\mathrm{~cm} \text {. }\end{array}$ & $\begin{array}{l}\text { Filippe Ferreira de Araújo e } \\
\text { Castro }\end{array}$ & $\begin{array}{l}\text { Localização: 113,4,21. Com o carimbo da } \\
\text { Biblioteca de Francisco Ramos Paz. O } \\
\text { segundo exemplar conhecido pertence a } \\
\text { minha coleção particular, adquirido em } \\
2015 \text { num alfarrabista em Lisboa. }\end{array}$ \\
\hline $\begin{array}{l}\text { ATALA // OU // OS AMORES // DE // } \\
\text { DOUS SALVAGENS // NO DESERTO; // } \\
\text { PELO VISCONDE DE CHATEAUBRIAND. } \\
\text { // NOVA EDIÇÃO REVISTA E } \\
\text { EMENDADA. // // EM LONDRES. // // } \\
\text { 1818. 8 } 8^{\circ}, 151 \mathrm{p} .\end{array}$ & $\begin{array}{l}\text { Filippe Ferreira de Araújo e } \\
\text { Castro / Hipólito José da Costa }\end{array}$ & $\begin{array}{l}\text { O único exemplar localizado está } \\
\text { conservado no Gabinete de Leitura } \\
\text { Português no Rio de Janeiro. }\end{array}$ \\
\hline $\begin{array}{l}\text { Atala, ou os Amores de dous Salvagens } \\
\text { (sic) no deserto, pelo Visconde de } \\
\text { Chateaubriand. Paris: A. Bobée, 1818. 18. }\end{array}$ & $?$ & $\begin{array}{l}\text { Não foi localizado exemplar. Os dados } \\
\text { foram obtidos Catalogo de Livros } \\
\text { Portuguezes: obras novas. Paris: Officina de } \\
\text { J. Smith, rua Montmorency, n. 16,[1827] } \\
\text { p. } 1 .\end{array}$ \\
\hline $\begin{array}{l}\text { ATALA // OU // OS AMORES // DE // } \\
\text { DOUS SELVAGENS NO DESERTO, // } \\
\text { POR // FRANCISCO AUGUSTO // } \\
\text { CHATEAUBRIAND. // TRADUZIDO // NA } \\
\text { // LINGUAGEM PORTUGUESA // POR } \\
\text { *** // BAHIA: // NA TYPOG. DE } \\
\text { MANOEL ANTONIO DA // SILVA SERVA. } \\
\text { // ANNO DE } 1819 .\end{array}$ & $?$ & $\begin{array}{l}\text { Há exemplar dessa obra na Biblioteca } \\
\text { Nacional de Lisboa, ref. L. } 8609 \text { P., e na } \\
\text { Coleção José e Guita Mindlin na USP, que } \\
\text { pertenceu a Rubens Borba de Moraes. Este } \\
\text { é o mesmo exemplar que aparece no } \\
\text { Boletim no } 59 \text {, da Livraria R. B. Rosenthal, } \\
\text { de Lisboa, oferecido por } 300 \text { escudos. Foi } \\
\text { ele adquirido pelo prof. Heitor Martins, } \\
\text { residente em New Orleans, e cedido ao } \\
\text { bibliógrafo paulista. Por fim, há o exemplar } \\
\text { que pertenceu Renato Berbert de Castro, } \\
\text { atualmente na Universidade Federal do } \\
\text { Recôncavo da Bahia, em Cachoeira. }\end{array}$ \\
\hline $\begin{array}{l}\text { ATALA, // OU // OS AMANTES DO } \\
\text { DEZERTO. // A HARMONIA DA } \\
\text { RELIGIÃO CHRISTÃ COM AS // SCENAS } \\
\text { DA NATUREZA E PAIXÕES DO // } \\
\text { CORAÇÃO HUMANO. // Nova Edição. // } \\
\text { [Armas de Portugal] // LISBOA, // NA } \\
\text { IMPRESSÃO REGIA. // ANNO 1820. // } \\
\text { Com Licença. // Vende-se na Loja de Jorge } \\
\text { Rey, // Mercador de livros, aos Martyres. } 8^{\circ} \\
157 \text { p. }\end{array}$ & $\begin{array}{l}\text { Filippe Ferreira de Araújo e } \\
\text { Castro }\end{array}$ & $\begin{array}{l}\text { Há um exemplar na Biblioteca Nacional de } \\
\text { Portugal e o segundo na minha coleção } \\
\text { particular. }\end{array}$ \\
\hline
\end{tabular}


O manuscrito da Atala nos Arquivo Nacional da Torre do Tombo também oferece informações valiosas para entender a censura da primitiva tradução de 1810. A licença de impressão, que se pode ler no verso do último fólio, foi concedida pela Real Mesa Censória, meses antes do manuscrito seguir para o prelo: "Impr. ão p. desp. ' de Lix. ${ }^{\text {a }} 6$ de 8bro de 1809". A acompanhar o original de imprensa, existe um parecer, inçado de ironias, do censor régio Lucas Tavares, letrado de reconhecida erudição, que elogia a tradução:

Senhor. Li a obra intitulada Atala: a qual, alem de conter uma Moral pura, está excelentemente traduzida, o que é raro em nossos dias; pois que o comum dos Tradutores é não saberem Francês, nem Português. Parece-me que Vossa Alteza Real pode conceder ao Suplicante a licença que pretende. Lisboa 2 de Outubro de 1809. Lucas Tavares. ${ }^{14}$

Com a licença expedida, a edição da Atala de 1810 deve ter vendido bem. Em abril de 1812, o livreiro e impressor de origem francesa Francisco Rolland, radicado em Lisboa, requereu à Real Mesa Censória a obtenção da licença para nova impressão da Atala ou os Amores de Dous Selvagens no Deserto. Esse pedido mereceu o seguinte parecer da mão do censor régio Frei José Joaquim da Imaculada Conceição:

Senhor. Por ordem de Vossa Alteza Real revi a Obra intitulada Atala, ou os Amores de dois Selvagens. Em ela não encontro coisa que desmereça a Graça da Impressão. Real Convento de São Francisco de Cidade de Lisboa 2 de Abril de 1812. Fr. José Joaquim da Imaculada Conceição. ${ }^{15}$

José Timóteo da Silva Bastos afirmou, na sua História da Censura Intelectual em Portugal, referindo-se à proibição que recaiu sobre a tradução de 1810, que "é curioso que o Atala ou os amores de dois selvagens no deserto, de Chateaubriand, fosse suprimido e escusado na Mesa. Tinha parecer favorável do censor Frei José Joaquim da Imaculada Conceição e do Ordinário."16 Thierry dos Santos que também examinou o manuscrito da Atala elaborou as seguintes observações à partir do mesmo:

esta unanimidade em torno da versão de Araújo e Castro é fruto de certas providências cautelares que tanto o tradutor como, possivelmente, o editor souberam tomar, ao

\footnotetext{
${ }^{14}$ Arquivo Nacional / Torre do Tombo, fundo Real Mesa Censória, caixa no 67, maço 44.

${ }_{15}^{15}$ Arquivo Nacional / Torre do Tombo, fundo Real Mesa Censória, caixa n 71 , maço 74.

${ }^{16}$ BASTOS. Op. Cit., p. 166.
} 
proceder a leves mas significativas adaptações e distorções do texto, a começar pelo título. Atala ou os Amantes do Deserto não sugere o mesmo que Atala ou les amours de deux sauvages dans le désert (Paris: 1801). Na verdade, o título aparece edulcorado, pois troca "os amores de dois selvagens", do qual se poderia esperar alguma indecência se associarmos a ideia de "selvagens" à de "amores", pelos "amantes", termo então nobre, evocando uma relação amorosa de pendor galante. [...] Foi assim que o tradutor deu uma ênfase cultural bastante diferente daquela que o original preconiza, ao configurá-lo com reforço de tópicos neoclássicos e com redução da carga exótica. Deste modo não é de estranhar que, quer por razões de índole estética, quer por medida de salvaguarda de si próprio e do seu projecto, o tradutor tenha procedido à domesticação de conteúdos potencialmente ofensivos ou estranhos, praticando uma censura cultural. $^{17}$

O estratagema deu certo por dois anos e o livro circulou em Portugal. Em dezembro de 1812, apesar de todas aquelas precauções, o censor João Baptista Rodrigues Leitão expediu a censura daquela obra, conforme declarou na ata abaixo:

O Conselho Geral do Santo Oficio manda remeter a Vossa Majestade o Manuscrito incluso, intitulado Atala, ou os Amores de dois Selvagens no Deserto com a cópia da Censura, que envio junto, com a qual o mesmo Conselho se conforma, para que tudo seja presente na Mesa do Desembargo do Paço. Deus Nosso Senhor Guarde a Sua Majestade. Lisboa 7 de Dezembro 1812. Senhores José Frederico Ludovici / João Baptista Rodrigues Leitão.

Dá-se então o que Thierry Proença bem definiu como "o paradoxo da Censura": o Conselho Geral do Santo Ofício opõe-se à impressão do livro, com base no parecer de João Baptista Rodrigues Leitão cuja decisão determinou que o livro estaria adiante "escusado e suprimido para Despacho de 30 de Outubro de 1812". Na sua "cópia da Censura", Leitão evocou Jacques Bossuet com o objetivo de conferir ao seu discurso autoridade moral e atacar, em seguida, as teorias dos filósofos setecentistas franceses que à Moral opõem as forças da Natureza. Desenvolveu considerações gerais sobre o "voto de Castidade" que designa como o elemento mais questionável da obra, rejeitando a forma como Chateaubriand abordou a questão ao associá-lo a uma jovem índia, motivada por "paixões tumultuosas", inconsciente do valor que tem "este dom do Espírito Santo" e incapaz de "enfrear os impulsos e rebeldia da carne com as ideias do Céu". Como se isso não bastasse, o principal personagem acaba por se suicidar "com veneno, persuadida que este é o modo de livrar sua mãe das

${ }^{17}$ SANTOS. "Atala traduzida em tempos de censura", p.5. 
penas do Inferno." Seguindo essa orientação, o censor chega à conclusão de que "isto não é ensinar, é desinquietar, é destruir." Faz de seguida o resumo da obra para, finalmente, transcrever os trechos que considera espúrios e que divide em três tópicos: as "blasfêmias", a "heresia" e as "passagens indecentes". Remata de um modo peremptório: "tudo isto é perigoso: são as tuas lições, filosofia do Século".

Thierry dos Santos observou que "Curiosamente, o censor do Santo Ofício não considera o autor sacrílego (não chegando a nomeá-lo, ou por ignorância ou então de propósito), mas sim o tradutor, ao designá-lo culpado deste atentado ao Dogma". 18 A Ata da Censura foi finalizada com a frase "o Tradutor que se defenda". ${ }^{19}$ Isso explica a suma raridade dos exemplares da edição de 1810.

Não há registro de que o tradutor tenha se defendido. Um amigo seu, contudo, o fez. Hipólito José da Costa teve acesso a um exemplar da primeira tradução portuguesa e, como que respondendo ao arremate do censor Rodrigues Leitão, publicou uma veemente defesa da obra e do tradutor nas páginas do Correio Braziliense, editado em Londres. A descrição feita por Hipólito não deixa dúvidas de que possuía mesmo a primeira edição: "Atala ou os Amantes do deserto (...). Lisboa. 1810. 1 vol. em 12. p. 157”. O jornalista e insigne pedreiro-livre declarou que

A immensidade de novellas que se tem publicado durante o secculo passado, e neste, a insipidez, inutilidade, e muitas vezes depravaçaõ destas publicaçoens, tem feito characterizar esta sorte de composiçoens, como uma leitura somente própria de espíritos frivolos, e como um emprego inútil, quando nao seja de consequencias funestas á moral do leitor. Não entram porém nesta classe as novellas fundadas em principios da verdadeira moral, e tendentes a inspirar no leitor as máximas de prudência, e as regras de conducta, que se incluem nas paridades, e emblemas, que divertindo o espirito, formam o entendimento, e regem o coração. Taes são um Telemaco, um Feliz independente do mundo e da Fortuna; e tal he a Atala. Esta novella se imprimio em Portuguez sem nome d'author; mas o seu original Francez, se acha na obra de Mr. Chateaubriand, intitulada "Le génie du Christianisme," no vol. 3, p. 240; e o traductor que também occultou o seu nome, empregando-se nesta traducçaõ, mostrou o seu bom discernimento no objecto, suas philantropicas intençoens, em dar esta obra a seus concidadãos na lingua materna, e a sua instrucçaõ nas belas expressoens com que interpreta sempre o genuíno sentido do Author.

Nos conhecemos as objecçoens, que se tem feito a esta obra; principalmente deduzidas de ser ella destinada unicamente a mostrar, quanto a religião Christaã tende á felicidade dos homens neste mundo, os adversários do A. insistem em que este systema dá uma

${ }^{18}$ Idem, p. 7

${ }^{19}$ ANTT. Real Mesa Censória, no 4028

115| EN S A I O S 
idea totalmente humana da religião, quando ella he puramente divina, e tendente a procurar-nos a felicidade da vida futura.

Parecenos que esta objecçaõ he de mui fácil resposta, e tanto mais quanto a Escriptura Sagrada em muitos lugares inculca o prêmio temporal que a practica das virtudes religiosas nos procura. " Honra a teu pay, e a tua may; para que vivas longo tempo sobre a terra. (...) Ademais; quando tantos escriptores, inimigos do Christianismo, se tem esforçado em pintar a religião Christaã, como productora de males temporaes, e por consequencia opposta á felicidade dos homens neste Mundo, nada podia combater estes escriptores com melhor successo do que uma obra, que tem por designio o mostrar as felicidades que a religião Christaã tem trazido ao Mundo.

A novella, de que se tracta, he para assim dizer, uma recopilaçaõ practica dos theoremas que o A. tem demonstrado pela razaõ, e pelos factos históricos; e pinta cora justa energia os sentimentos que a religião inspira, em uma alma virtuosa sem affectação, religiosa sem fanatismo, e bem morigerada sem ser demasiado austera. (...) E quanto a fidelidade da traducçaõ, elle se não cinge ao original mais do que he necessário para seguir as ideas do A., de que algumas vezes se desvia algum tanto. Bem longe de censurarmos esta liberdade do Traductor, a julgamos necessária em muitos casos, para adoptar á natureza da linguagem, e aos custumes da nação, as ideas originaes; e preencher o desígnio do A.; principalmente em obras desta natureza, em que a forma das expressoens, naõ he da essência ao sentido ; nem necessária ao systema. ${ }^{20}$

Um detalhe a ressaltar nesta crítica favorável é que o parecer de Hipólito José da Costa pode estar comprometido por uma dívida de gratidão com o tradutor da Atala. Foi Filippe Ferreira de Araújo e Castro quem lhe salvou a vida, sete anos antes de o jornalista publicar o artigo acima no Correio Brazilense. Após a sua picaresca fuga dos Estaos do Santo Ofício em 1805, onde estava desde 1802, com o corregedor José Anastácio Lopes Cardoso e o intendente da Polícia Pina Manique no seu encalço, o célebre pedreiro-livre brasílico recorreu aos seus amigos maçons em Lisboa, acionando uma rede oculta de indivíduos que incluía até mesmo o neto do Marquês de Pombal. Foi elaborado, então, um plano para retirar Hipólito da Costa de Portugal com o auxílio da maçonaria. Parte desse plano para garantir a liberdade de Hipólito consistia em fazê-lo se passar por criado de Filippe Ferreira de Araújo e Castro, com o objetivo de cruzar a fronteira com a Espanha, seguindo para Gibraltar, de onde passou para a Inglaterra. ${ }^{21}$ A fuga de Hipólito da Costa e a participação de Araújo e Castro no episódio, se não comprova, é um forte indício de que o tradutor da Atala também estava associado às agremiações maçônicas de Lisboa.

\footnotetext{
${ }^{20}$ Correio Braziliense, Vol. IX. N.53, outubro, 1812. pp. 590-95. Agradeço a Hélida Santos Conceição por digitalizar, a meu pedido, a edição inglesa do Gabinete de Leitura do Rio de Janeiro.

${ }^{21}$ CARVALHO, José Liberato Freire de. Memorias da Vida de José Liberato Freire de Carvalho. Lisboa: Typographia de José Baptista Morando, 1855 p. 45.
} 
Por diligência de Hipólito José da Costa a impressão da Atala foi realizada em Londres em 1818. Além da gratidão de Hipólito para com Araújo e Castro e da sua veemente defesa do livro em 1812, reforça essa afirmação o exame dos tipos móveis empregados naquela impressão, que permitiu confirmar que a novela foi impressa por L. Thompson, estabelecido em Great St. Hellens, Londres, o mesmo tipógrafo que deu prelo ao Correio Braziliense entre 1818 e 1819. Há outra coisa a ser considerada na Atala impressa em Londres. A sua tradução sofreu intervenções pontuais e não é a mesma das edições lisboetas de 1810 e 1820. O título foi restituído de acordo com o original francês, ficando também mais próximo da tradução feita em Salvador no ano seguinte. O exame do exemplar do Gabinete Português de Leitura confirma que o texto foi refeito sobre a tradução da edição de 1810, de Araújo e Castro, mas sem as preocupações com a censura portuguesa. Por isso, o texto foi restituído de acordo com o original francês, mantendo o título e os capítulos, o que de fato constituí uma "Nova edição revista e emendada", conforme anunciado no frontispício. Hipólito da Costa, que conhecida bem a língua francesa, fez a revisão e as emendas. Apenas em 1823 Araújo e Castro seguiria, exilado, para a Inglaterra.

É notável, contudo, que todas as três variantes identificadas mantêm o tradutor sob anonimato. Thierry dos Santos observou que do tradutor se exigia, naquele contexto de censura intelectual, "discernimento na escolha da obra a traduzir, apuramento do estilo e da gramática da língua receptora, bom conhecimento da língua fonte e, sobretudo, uma modéstia a toda a prova, cuja maior expressão é o anonimato". ${ }^{22}$ Quebrar esse anonimato, contudo, é necessário, hoje, para o historiador que deseja desenvolver uma leitura polissêmica do texto. No caso da Atala, identificar os tradutores é necessário, inclusive, para compreender as sociabilidades e os projetos políticos em que aqueles sujeitos estavam imersos, em Londres, Lisboa e na Bahia. Foi Inocêncio Francisco da Silva o primeiro a atribuir a Filippe Ferreira de Araújo e Castro a tradução da edição de 1810/1820. As indicações registradas no manuscrito da Real Mesa Censória (ANTT, RMC, n.4028) confirmam a atribuição feita pelo bibliógrafo português. $\mathrm{O}$ anônimo tradutor baiano, contudo, é mais difícil de ser identificado. Exatamente dois séculos depois, não há qualquer registro de quem verteu para o português a novela impressa na Tipografia de Manoel Antonio da Silva Serva.

${ }^{22}$ SANTOS. "Atala traduzida em tempos de censura", p.8.

$117 \mid$ E N S A I O S 


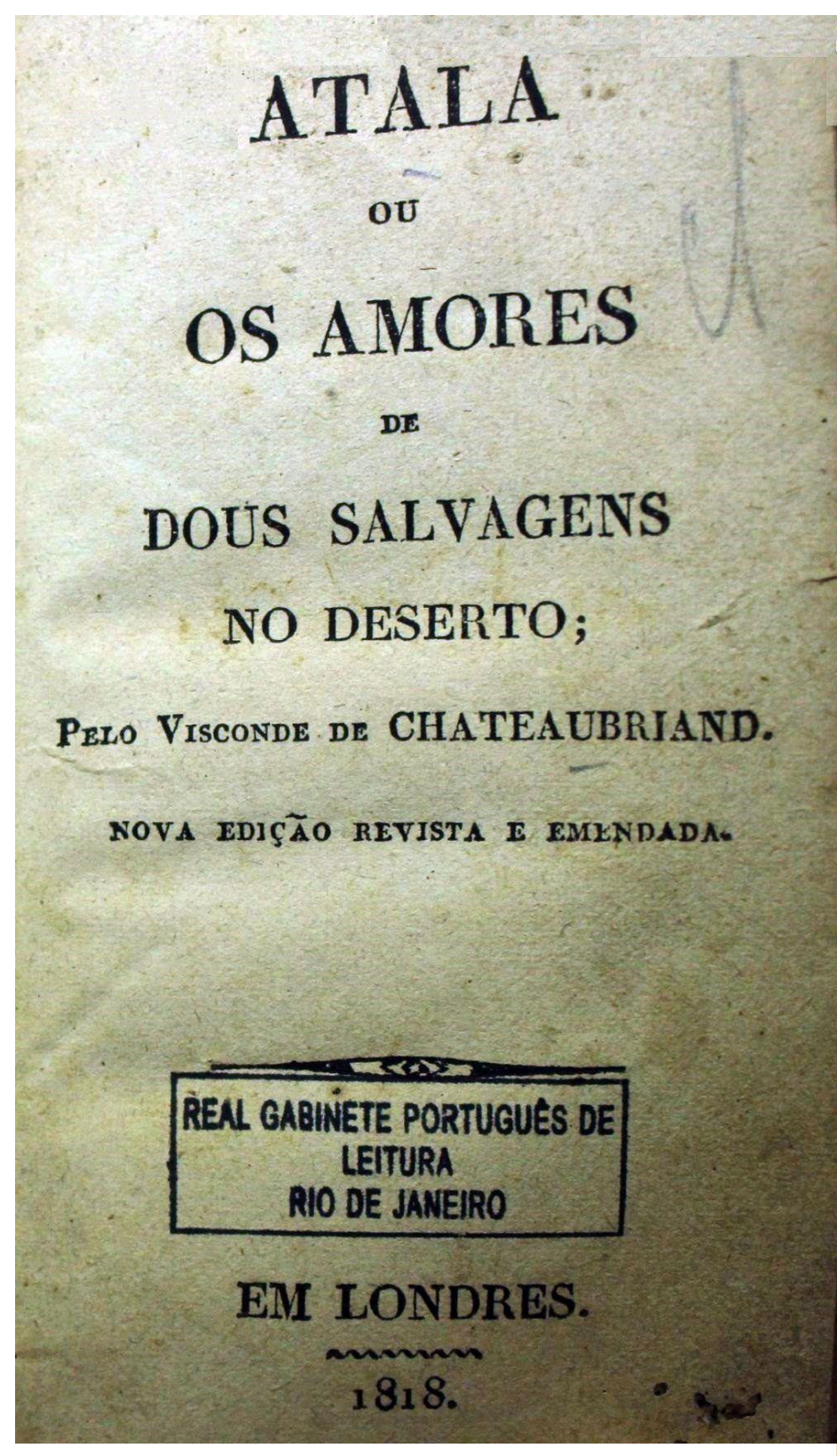

Frontispíco das edições de Londres 1818 e Lisboa 1820.

Gabinete Português de Leitura e Coleção do Autor, respectivamente.

\section{A T A L A,}

OU

\section{OS AMANTES DO DESERTO.}

A HARMONIA DA RELIGIẢO CHRISTÄ COM AS SCENAS da NATUREza e PaIXóEs do CORAÇÃo humano.

Nova Ediçăo.
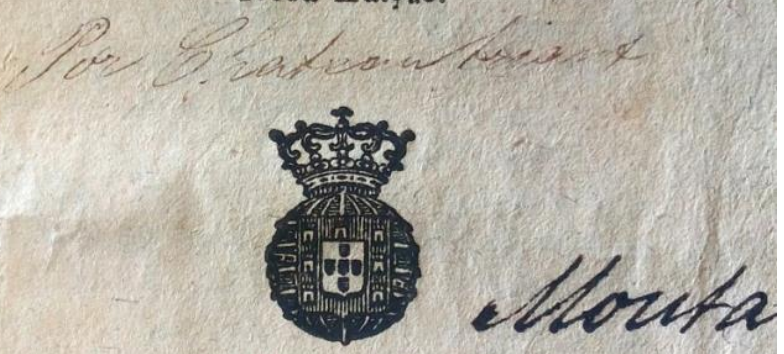

L I S B O A, NA I MPRESSÄO REGIA.

$\frac{\text { Asno } 1820 .}{\text { Com Licença. }}$

Vende-se na Loja de Jorge Rey, Mercador de livros, aos Martyres. 
Retomando a comparação, realizada por Thierry Santos, entre as duas traduções a que ele teve acesso, é perceptível que o título da edição bahiense ${ }^{23}$ assevera que o seu tradutor possuía mais conhecimentos da pronúncia francesa do que o tradutor da edição lisboeta. Em relação ao nome da protagonista, "o certo é que a forma 'Atalá' denota respeito pela identidade sonora de origem, dando maior relevância ao traço oral, enquanto a manutenção da grafia original 'Atala' denota respeito pela identidade gráfica de origem, percebendo-se aqui o primor da escrita". Ainda segundo aquele pesquisador, o mesmo fenômeno pode ser percebido na pronúncia de outros antropônimos originais à francesa: "Chactás", "Siminóles" e "Endaé" Ora, isso demonstra que o tradutor baiano não apenas conhecia a língua francesa, mas a sua pronúncia correta.

Santos comparou a tradução bahiense de 1819 com o exemplar lisboeta de 1820 e percebeu significativas alterações no segundo, em virtude da necessidade de submeter o texto ao parecer da Real Mesa Censória. Imagens que remetiam a elementos religiosos foram suprimidas da edição lisboeta de 1810 e de 1820, permanecendo conforme o original francês nas edições de Londres e de Salvador:

[A] Des serpents verts, des hérons bleus, des flamants roses, de jeunes crocodiles s'embarquent passagers sur ces vaisseaux de fleurs, // As Garças, as Flamantes, e mil outras Aves lindas se embarcão passageiras nestes baixeis de flôres; (1810:5) // Garças azues, flamantes côr de fogo, serpentes verdes, crocodilos pequenos se embarcão passageiros nestes baixeis de flores (1818: 7 e 8) // Serpentes verdes, garças reaes azues, flamants côr de rosa, e ternos crocodilos se embracão por passageiros nestes navios de flores (1819:8)

[B] Jésus-Christ n'a pas dit: Mon sang lavera celui-ci, et non pas celui-là. 'Il est mort pour le Juif et le Gentil, et il n'a vu dans tous les hommes que des fréres et des infortunés / Jesus Christo disse, o meu sangue lavará este, e não aquelle? Ele morreo pelo Indio, e pelo Gentio, e só considera os ómens como irmaons, e infelizes (1810: 72) / Jesu Christo disse: Meu sangue purificará este, e não aquelle? Elle morreo pelo Judeo, e pelo Gentio, em em todos os homens não vio senão irmãos, e desgraçados (1819: 9495)

[C] Phillippe était son nom parmi les anges, et les hommes le nommainet Lopez / Felipe era seo nome entre os Genios, e os O'mens lhe chamavão Lopes (1810: 68) / Filippe era o seu nome entre os Anjos, e os homens o chamavão Lopez (1818: 70-71) / Filipe era o seu nome entre os Anjos, e os homens o chamavão Lopes (1819: 89)

\footnotetext{
${ }^{23}$ No presente texto, em virtude de se tratar de um livro impresso na colônia, é preferível utilizar o adjetivo pátrio bahiense ao invés de baiano, conforme se utilizava na época.

${ }^{24}$ SANTOS. Atala Traduzida - Estudo das Primeiras Versões Portuguesas, 1999, p. 209.
} 
Há outros exemplos de substituição de palavras. No original Chateaubriand usou a expressão "savanes", sendo que na edição portuguesa foi usado o termo "prados" (1820:8) enquanto o tradutor da Bahia usou a expressão "vargens" (1819:9). Santos ainda observou que Filippe Ferreira Araújo e Castro traduziu a novela em um português de cunho setecentista. $O$ tradutor da versão impressa na Bahia o fez numa linguagem mais contemporânea e sofisticada. Quem seria, então, o anônimo tradutor da edição de 1819 ?

\section{A edição bahiense de Atala (1819) e o seu anônimo tradutor}

Não há dúvida de que a tradução de 1819 da Atala foi realizada na Bahia e, inclusive, foi anterior às edições portuguesas de Londres e Paris. O manuscrito com a referida tradução foi submetido ao exame do poeta e professor régio José Francisco Cardoso de Moraes, autor do Canto de Tripoli (Arco do Cego, 1800) e membro mais atuante da Comissão de Censura criada pelo Conde dos Arcos em 1811. O Arquivo Público do Estado da Bahia conserva o registro da censura da edição bahiense:

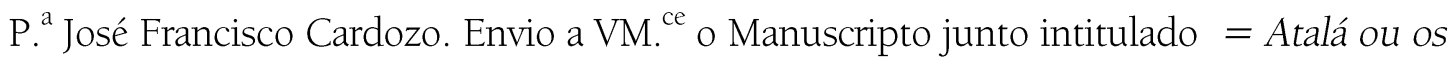
Amores de dois Selvagens no Deserto $=$ p. ${ }^{\text {a }} \mathrm{q}$. me informe se está nas circunstancias de permitir q. se dê ao prelo. Deos g. ${ }^{\mathrm{e}}$ a VM. ${ }^{\text {ce }}{ }^{\text {B. }}{ }^{\mathrm{a}} 20$ de Julho de 1817. Conde dos Arcos. Sr. Proff. ${ }^{\text {or }}$ Jose Franc. ${ }^{\mathrm{co}}$ Cardozo. ${ }^{25}$

Assim, segundo o registro acima, é possível afirmar que a tradução bahiense da Atalá já estava pronta em julho de 1817, dois anos antes de ser impressa pela Tipografia de Manoel Antonio da Silva Serva. É razoável considerar que tradução pode ter sido realizada entre 1816 e o primeiro semestre de 1817. Permanece uma questão: quem poderia ser o tradutor do texto para a edição bahiense?

Para responder a essa questão, após dois séculos, o primeiro elemento a ser considerado, reconhecendo que se trata de uma tradução original, diferente das suas congêneres de Lisboa, Londres e Paris, é o conjunto dos intelectuais que circulavam junto a Tipografia de Manoel Antonio da Silva Serva, a única que então existia na Bahia. O segundo elemento a se considerar é quais desses indivíduos dominavam com suficiente competência o idioma francês para

${ }^{25}$ Arquivo Público do Estado da Bahia. Seção Colonial/ Provincial. Cartas do Governo, maço 170 (1817-1819), fl. 145. 


\section{A $\mathrm{T} \mathrm{C}$ G U \\ OS AMORES. \\ D $\mathrm{B}$}

DOUS SELYAGENS NO DESERTO, Ho nty

ERA ACISCO AUGUSTO CHATEAUBLAN D.

$$
\text { TRADUZIDO }
$$

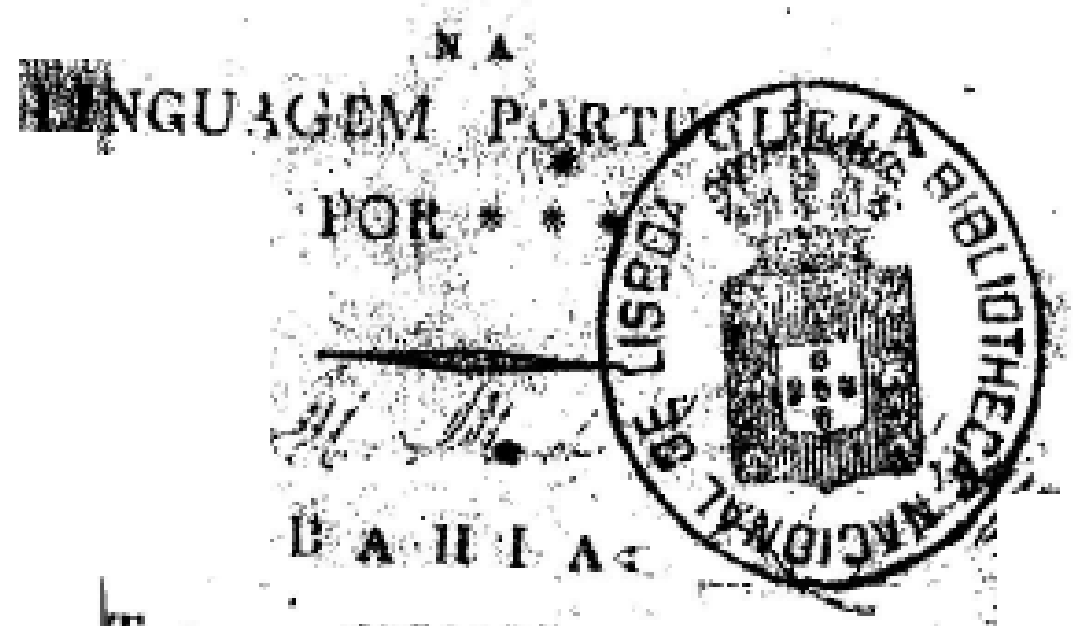

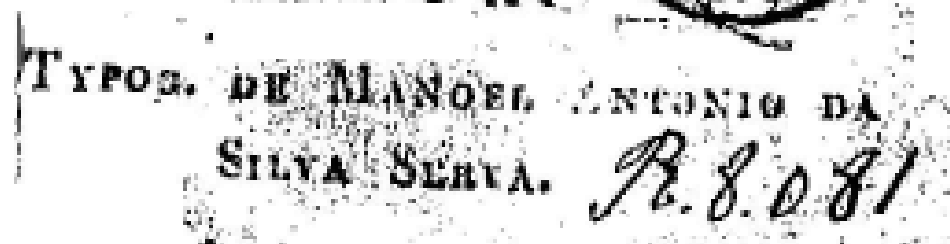

ANXO DE 1810.0

Exemplar da Biblioteca

Nacional de Portugal 
realizar uma tradução com as qualidades linguísticas assinaladas acima. A terceira razão é compreender os motivos que levariam um tradutor a se manter anônimo. Além disso, o caminho que percorreu o manuscrito no processo de censura permite observar alguns indícios que apontam para a presença do tradutor de Atala na Bahia, visto ele ter acesso ao Conde dos Arcos.

Examinando o conjunto de intelectuais (autores, tradutores, oradores, médicos, jornalistas, poetas, professores) que estavam ligados à Tipografia de Serva entre 1811 e 1819, alguns podem ser excluídos de imediato como possível tradutor da Atalá. O próprio José Francisco Cardoso de Moraes obviamente está fora de questão, já que não há sentido em ele próprio fazer a censura do manuscrito de sua autoria. Além do mais, não há notícias de que tenha realizado traduções dos seus escritos para o francês, tão pouco traduções do francês para o português. Sua obra magna, o poema latino sobre a guerra em Trípoli, vertido por Bocage em português, foi traduzido para o francês em 1847, mas por Delatour.

O padre Ignacio José de Macedo, um dos redatores da Idade d'Ouro do Brazil e personagem bastante presente na Tipografia de Serva, não pode ter sido o tradutor da Atalá. Apesar de sua significativa obra jornalística, paranética, poética, histórica e até mesmo traduções de filosofia latina, não era possível ao padre Macedo fazer uma elegante tradução de um texto em língua francesa, visto que ele próprio afirmar não a conhecer. O Velho Liberal do Douro, apelido que o próprio Macedo se atribuiu, revelou: "aprendi Francez sendo muito pequeno, e mal pronunciava algumas palavras. Contentava-me em entender o que lia em Francez, Inglez, Italiano, e não sei fallar essas línguas". ${ }^{26}$ Logo, é fora de questão ser Macedo o tradutor da Atalá, já que sequer falava aquela língua, quanto mais conhecer a pronúncia correta empregada na edição de 1819. Além disso, a escrita gaiata de Macedo é muito diferente da escrita sóbria e elegante com que a novela de Chateaubriand foi traduzida na Bahia.

Em torno da Tipografia de Serva havia outros intelectuais que conheciam bem a língua francesa, mas que podem ser facilmente desacreditados como tradutor da Atalá. O médico Manoel Joaquim Henriques de Paiva, que já havia sido processado pelo Santo Ofício de Coimbra, conhecia profundamente o idioma francês, traduzindo na Bahia as obras químicas de Fourcroy. Em seu amplo conjunto de obras traduzidas do francês, Henriques de Paiva conta

\footnotetext{
${ }_{27}^{26}$ O Velho Liberal do Douro, n. 38, Lisboa, Imprensa da Rua dos Fanqueiros, 1833, pp. 358-359.

27 IGLESIAS MAGALHÃES, P. A. . "Ignacio José de Macedo: da Idade d'Ouro ao Velho Liberal do Douro (1774-1834)". Revista do Instituto Geográfico e Histórico da Bahia, v. 108, p. 221-262, 2013.
} 
apenas obras médicas e de natureza científica. José da Silva Lisboa, insigne liberal autor de obras econômicas e de direito mercantil nunca se interessou por novelas e preferia o uso dos pseudônimos ao anonimato, ao longo de toda sua vasta obra. ${ }^{28} \mathrm{O}$ professor mineiro José Eloy Ottoni, tradutor da Parafraze de Salomão (Bahia, 1815), apesar de ter domínio sobre muitos idiomas, só verteu obras latinas para o português, de que são exemplos, além da já indicada, aa sua versão dos Livro de Jó (Rio de Janeiro, 1852) e do Stabat Mater. Esse conjunto de autores, acima elencados, é responsável pela maior parte das obras impressas pela Tipografia de Manoel Antonio da Silva Serva entre 1811 e 1819.

Excluídos todos os indivíduos acima, resta analisar outro personagem com estreitas ligações junto a Tipografia de Serva: Diogo Soares da Silva e Bivar (6 de fevereiro de 1785 - Rio de Janeiro, 10 de outubro de 1865). Colaborador de Ignacio José de Macedo na redação de a Idade d'Ouro do Brazil, Bivar tomou parte na redação da revista As Variedades, considerada a primeira do Brasil, publicada em 1812. ${ }^{29}$ É tido ainda por autor do Almanaque da Bahia para 1812, impresso em fins de 1811, também o primeiro do gênero no Brasil.

Primeira questão que se impõe: Bivar conhecia bem a língua francesa? Decerto, como dito, havia na capitania da Bahia um significativo número de intelectuais ilustrados que dominavam o idioma francês e a Biblioteca Pública da Bahia possuía, aliás, mais livros em francês do que em qualquer outra língua, incluindo a portuguesa. Contudo, apenas Bivar ousou, numa época em que francesia e jacobinismo eram praticamente sinônimos na Bahia, escrever e imprimir em Salvador um pequeno compêndio gramatical francês. Ele publicou na Bahia, em 1811, anonimamente, os Principios Geraes ou Verdadeiro Methodo para se aprender a lêr, e a pronunciar com propriedade a Lingua Franceza, na Tipografia de Manoel Antonio da Silva Serva; folheto com 22 páginas. Esse compêndio gramatical foi tão bem recebido que o livreiro Francisco Rolland, o mesmo que pediu licença para publicar a Atala em 1812, imprimiu a segunda edição na capital portuguesa em 1820, com 32 páginas, também anonimamente.

Diogo Soares da Silva e Bivar, mais do que todos os outros intelectuais que viviam na Bahia, precisava se manter anônimo. Sua biografia, pouco conhecida pelos historiadores, é singular. Bivar encontrava-se preso em Salvador

\footnotetext{
${ }^{28}$ IGLESIAS MAGALHÃES, P. A. "Flores Celestes (1807): O livro secreto de José da Silva Lisboa, o visconde de Cairú". Revista de Indias, Madrid, v. 73, p. 789-824, 2013

< http://dx.doi.org/10.3989/revindias.2013.26 > . Acesso em: 16 de maio de 2017

${ }^{29}$ VIANA, Hélio. "A primeira revista literária brasileira". Revista brasileira, n. ${ }^{\circ} 5$ (mar 1943), p. 11-31.
} 
desde 1810, aonde chegou aos 24 anos, destinado ao degredo em Moçambique. ${ }^{30}$ Traduzir um livro que já estava proibido em Portugal não lhe ajudaria a sair da cadeia. Sua única alternativa era o anonimato, que, aliás, ele já observara tanto nas Variedades quanto no Almanaque. É, então, necessário entender as razões que o levaram à prisão.

Diogo Soares da Silva e Bivar era filho do médico Rodrigo Soares da Silva e Bivar (1722-1809), estabelecido na Vila de Abrantes e formado na Universidade de Coimbra. O doutor Bivar, a crer num artigo escrito pelo seu neto, ascendeu socialmente após curar de uma grave enfermidade Francisco Xavier de Mendonça, irmão do Marquês de Pombal. ${ }^{31}$ Seu filho, o jovem Diogo, cursou Direito em Coimbra e retornou para sua vila natal, onde ocupou cargos públicos como inspetor de plantação de amoreiras, diretor da fiação de bichos de seda e administrador de tabacos. A história da família Bivar é inçada de controvérsias. Apesar de evocarem a descendência do espanhol El Cid Campeador, é bem possível que fossem cristãos-novos na Vila de Abrantes, fronteira com a Espanha.

Diogo Soares da Silva e Bivar era conhecido pedreiro-livre, segundo afirma o mais competente estudo sobre a maçonaria portuguesa. ${ }^{32} \mathrm{O}$ que permanece ignorado, até o presente, é que seu nome liga-se a outro pedreiro-livre, Filippe Ferreira de Araújo e Castro, o mesmo que retirou Hipólito da Costa secretamente de Portugal e traduziu a edição lisboeta da Atala. Os dois tradutores da Atala, Silva Bivar e Filippe Ferreira, eram confrades de longa data. Juntos atuaram na criação de uma sociedade literária denominada Sociedade Litteraria Tubucciana. Bivar capitaneou a fundação, a 13 de maio de 1802, na Vila de Abrantes, e serviu como secretário da referida Sociedade Tubuciana., definida por Oliveira Marques como uma sociedade paramaçônica. ${ }^{33}$ Seus

\footnotetext{
${ }^{30}$ AHU-Bahia, cx. 249, doc. 124 AHU_ACL_CU_005, Cx. 259, D. 18072. [ca. 1816] REQUERIMENTO de Diogo Soares da Silva Bívar, que fora preso no forte de São Pedro, na Bahia, e condenado ao degredo em Moçambique por traição contra o Estado no período da invasão francesa a Portugal, ao rei [D. João VI] solicitando perdão do crime.

31 BIVAR, Luiz Garcia Soares de. "O Sr. Conselheiro Bivar". A Regeneração. 21.10.1865. Reeditado no Jornal do Comércio, 30.10.1865

32 MARQUES, Antonio Henrique de Oliveira. História da Maçonaria em Portugal: das origens ao triunfo. Lisboa, 1990, Vol. 1, p. 351.

${ }^{33}$ Supplemento á Gazeta de Lisboa n. XXXIII. Sexta-feira 20 de agosto de 1802. pp.3 e 4. Havendo-se estabelecido na Villa de Abrantes huma Sociedade Litteraria, denominada Tubuciana, a diligencias de Diogo Soares da Silva e Bivar, pessoa bem conhecida da mesma Villa, a qual fez a sua abertura no dia 13 de Maio de 1802, por ser o dos Annos de S. A. R. Q Principe Regente N. S.; e tendo a mesma Sociedade formado hum Plano de Estatutos para o seu bom regime e governo económico, foi S.A. R. servido, por Aviso de 31 de Julho, dito, expedido pela sua Secretaria d'Estado dos Negócios da Real Fazenda, não só dar lhe a sua Regia Approvação, mas ordenar que se possa fazer público por meio do Prelo. O mesmo Senhor foi servido, por Decreto de 21 de Julho dito, fazer mercê ao referido Diogo Soares da Silva e Bivar do Habito da Ordem de Christo,em attenção aos muitos e relevantes serviços feitos por seu Pai Rodrigo Soares da Silva e Bivar, tanto na Guerra de 1762, como na próxima passada. GUERRA, Luís Bivar. "A Academia Tubuciana e os seus membros". In : A historiografia portuguesa anterior a Herculano, Academia Portuguesa da História, Lisboa, 1977, pp. 463490. Programma da Sociedade Litteraria Tubucciana de 15 de Janeiro de 1803 / [Diogo Soares da Silva e Bivar]. Lisboa : Regia Off. Typ., 1803.
} 
associados, além de Bivar, foram o presidente José de Macedo Ferreira Pinto, Filippe Ferreira de Araujo e Castro, Luiz Antonio Ferreira Bairrão, Fr. Luiz da Cumieira, Raymundo José da Silva Peres de Milão, Manuel Franco de Sequeira, Manuel José da Silva Paiva, João Pereira da Silva e Azevedo, Manuel Xavier da Rocha, Jacinto Luiz da Costa, Fr. Antonio de Penafiel, Francisco Xavier de Almeida Pimenta e o capitão Belchior Manuel Curvo Semmedo Torres de Sequeira (Belmiro Transtagano). De acordo com os Estatutos da referida sociedade:

Pelo aviso de 31 de julho de 1802, assignado por D. Rodrigo de Sousa Coutinho, foi declarado que approvára o principe regente os estatutos da Sociedade Litteraria denominada Tubucciana, estabelecida na villa de Abrantes. Ficava a mesma sociedade auctorisada, não só para celebrar as suas sessões na conformidade d'aquelles estatutos, senão tambem para dar-lhes publicidade por meio da impressão. O pensamento da creação d'esta sociedade deve ser attribuido a Diogo Soares da Silva e Bivar, que depois foi secretario d'ella, e do qual adiante havemos de referir algumas circumstancias e factos. Artigo 1. ${ }^{\circ}$ A sociedade toma o nome de Sociedade Litteraria Tubucciana. [...] Artigo 3. ${ }^{\circ}-$ Seu emblema será o sol sobre o horisonte; em frente um espelho ustorio, que no seu fóco ajunta todos os seus raios, e os reflecte com vehemencia, accendendo o facho ou pharol das sciencias. Artigo 4. ${ }^{\circ}-\mathrm{Seu}$ (sic) epigrafe: Virtus unita fortius agit. Artigo 5. ${ }^{\circ}$-Os socios são constituidos na mais ampla liberdade a respeito das memorias que devem apresentar; pois queremos que o vasto campo das Sciencias, e até das artes, seja aberto ás investigações dos alumnos para geral utilidade: e como para esta muito concorrem as traducções, ellas terão grande parte nos nossos trabalhos, procurando em tudo, quanto for possivel, o util com o deleitoso. [... Artigo 39. ${ }^{\circ}-$ Todos os annos haverá dois programmas: um em bellas lettras, e outro em agricultura; e este deverá tender, quanto seja possivel, para o melhoramento e vantagem d'esta villa e seu termo. ${ }^{34}$

De todos estes sócios, o que mais distinção alcançou foi Araujo e Castro, por conta de diversos cargos jurídicos e administrativos que galgou em Portugal. $O$ auge da sua carreira foi quando assumiu o cargo de Ministro dos Negócios do Reino no período constitucional de 1821 a 1823. Aliás, como Bivar, Araújo e Castro, mesmo após a extinção da Sociedade Tubucciana, manteve-se observando a recomendação feita no artigo $5 .^{\circ}$ dos estatutos daquela associação, traduzindo para o português as obras de moral, literatura e direito público, destacando-se, além do Atala, a Historia de Simão de Nantua, O bom homem Ricardo, de Benjamin Franklin, e o Estudo sobre a historia das instituições

\footnotetext{
${ }^{34}$ Estatutos, em que convieram os primeiros sócios da Sociedade Literária Tubuciana de Abrantes, aporvada pelo Principe Regente. Régia Off. Typográfica, 1802. [4], 5-26 p.
} 
politicas, litteratura, theatro e bellas artes em Hespanha por Mr. Wiardot, (1844). ${ }^{35}$ Com a extinção precoce da Sociedade Tubucciana e a Invasão de Portugal pelo Exército francês em 1807, os antigos confrades Diogo Soares e Filippe Ferreira seguiram caminhos distintos. O prestígio de Bivar seria minado após a invasão napoleônica, pelo auxílio que prestou às tropas napoleônicas chefiadas por Jean-Andoche Junot. O cronista José Acursio das Neves registrou que no dia 24 de novembro de 1807 entrou Junot em Abrantes com seu exército, ordenando

imediatamente ao juiz de fora José Macedo Ferreira Pinto que lhe fizesse aprontar 12 mil rações e 12 mil pares de sapatos, com a cominação de impor uma contribuição à terra de 300 mil cruzados novos, e o tratou tão asperamente que este digno magistrado logo na noite seguinte evitou com a fuga os resultados que podiam seguir-se. Ficando vago por este motivo aquele emprego, Junot, depois que tomou o governo do reino, o conferiu a um moço [Diogo Soares de Bivar], filho da mesma terra, que se não tinha habilitado nem frequentado as aulas da Universidade, querendo por esta forma mostrar-se agradecido a seu pai, Rodrigo Soares de Bivar, em cuja casa se aquartelara, pelas grandes despesas que fez na sua hospedagem. Até para o vestir lhe deu camisas! $!^{36}$

Afastado o perigo de invasão francesa, a denúncia contra Bivar tramitou sob a acusação de crime de inconfidência. ${ }^{37}$ A crer nas palavras do publicista José Agostinho de Macedo, Diogo Bivar esteve bem próximo do cadafalso pelo crime de colaboracionismo com as tropas de Junot:

\footnotetext{
${ }^{35}$ SILVA, Inocêncio Francisco da Silva. Diccionario Bibliographico Portuguez. Lisboa: Imprensa Nacional, 1860, T. II, p. 296 e 297

${ }^{36}$ NEVES, José Acúrsio das. História Geral da Invasão dos Franceses em Portugal. Lisboa: na Off. de Simão Thaddeo Ferreira, 18101811. Tomo I, cap. XVI

${ }^{37}$ Arquivo Nacional no Rio de Janeiro. Secretaria de Estado do Ministério do Reino. Fundo: Negócios de Portugal (n. 59), Caixa 659, pacote 01 (1782-1809) Certidão de prisão do réu Diogo Soares da Silva e Bivar, onde este é acusado de ter hospedado em sua casa, na vila de Abrantes, o general Junot no período em que o exército francês passou pela dita vila. Também é acusado de ter ficado tão "afeiçoado" aos invasores, que passados poucos dias da invasão, este foi até Lisboa solicitar o cargo de juiz de fora. Lisboa, 23 de maio de 1809. Arquivo Histórico de Abrantes, Livro de Actas da Câmara Municipal de Abrantes, fl. 66 v. O manuscrito está danificado por borrões de tinta para disfarçar seu conteúdo, mas ainda é possível reconhecer a assinatura de Diogo Soares da Silva e Bivar. O livro de 1807 foi propositadamente mutilado na sua parte final, e suas folhas arrancadas (fls. 79 a 96) e uma manchada com grossas pinceladas de tinta negra, de alto a baixo, para impossibilitar a leitura. Devia conter matéria importante e comprometedora para a vereação da altura, para ter sido assim riscado. Dá para entender, no entanto, que passou a assinar o colaboracionista Diogo Soares da Silva e Bivar, em vez do juiz de fora José de Macedo Ferreira Pinto. Na última página consegue-se ainda ler: «As folhas que faltam neste livro foram queimadas na fogueira (?) das ... de Sua Majestade». Faltam os livros de Atas da Câmara Municipal de Abrantes para os anos de 1808 a 1810
} 


\begin{tabular}{|c|c|}
\hline $\begin{array}{l}\text { Nem tu tornando, como espero, ó } \\
\text { Abrantes, } \\
\text { Tubuciana Academia acima } \\
\text { Farás ir outra vez: Bivar honrado, } \\
\text { Se um voto menos te livrou da } \\
\text { forca, } \\
\text { Não podeste evitar que em torno } \\
\text { d'ella } \\
\text { (Porque abafava com calor o dia) } \\
\text { Não d'esses vezes três serena volta, } \\
\text { C'o pardo e liso couro ao sol } \\
\text { patente, }\end{array}$ & $\begin{array}{l}\text { Onde ingénuo igual teu } \\
\text { Carrasco dicto } \\
\text { Descarregou sonora sapatada } \\
\text { Que o povo de prazer deixava } \\
\text { absorto, } \\
\text { Pedindo ao ceo que a } \\
\text { gargantilha tua } \\
\text { Se atasse nos paus três, onde } \\
\text { ondeante } \\
\text { Teu mascavado corpanzil } \\
\text { ficasse! }\end{array}$ \\
\hline
\end{tabular}

Bivar escapou da morte em 1809, mas foi humilhado, espancado e teve que dar três voltas em torno da forca. Nesses versos de José Agostinho de Macedo aparece um aspecto das características físicas do jovem inconfidente: a cor da pele. Descrito ora como pardo, ora como mascavado, Bivar deve ter tido a pele escura, ao modo dos mouriscos portugueses.

O castigo de Bivar foi comutado em degredo no Rio Sena, em Moçambique. ${ }^{39}$ Quando o navio que lhe conduziria para a África aportou na Bahia, Bivar "encontrou no conde dos Arcos, então governador d'aquella provincia, favor e protecção, que valeu ser-lhe commutado o degredo em outro mais suave para a propria provincia da Bahia". " A situação do jovem prisioneiro era grave e, enquanto estava preso em Salvador, na sua terra natal ficou determinado que "os bens do confiscado Diogo Soares da Silva e Bivar, na Villa de Abrantes, e que por partilha lhe couberão, se hão de rematar nas casas da residência do Desembargador Juiz do Real Fisco por Inconfidência José Antonio da Silva Pedrosa".

O que é singular na biografia de Bivar é que mesmo preso no Forte de São Pedro o réu recebeu imensas regalias por parte das autoridades do governo da Bahia, onde gozou de prestígio intelectual. Carl F. P. Von Martius cita Bivar como "o único dos nossos conhecidos que fizera observações meteorológicas

\footnotetext{
${ }^{38}$ MACEDO, José Agostinho de. Os Burros, ou o Reinado da Sandice: poema heroi-comico-satyrico em seis cantos. Paris: Na Officina de Rignoux, 1827, pp. 25-26.

${ }^{39}$ Arquivo Histórico Ultramarino, Bahia-Avulsos, Caixa 259, doc. 18.072. [ca. 1816]. REQUERIMENTO de Diogo Soares da Silva Bivar, que fora preso no forte de São Pedro, na Bahia, e condenado ao degredo em Moçambique por traição contra o Estado no período da invasão francesa a Portugal, ao rei [D. João VI] solicitando perdão do crime.

${ }^{40}$ SILVA. Op. Cit., Vol. IX, 1870, Pp. 129-130.

${ }^{41}$ Gazeta de Lisboa, n. 187. Quarta-feira, 10 de agosto de 1814. p.3. Executados na tarde de 25 de agosto e 1 de setembro.
} 
[...] firmou-nos poder calcular a temperatura ao pôr do sol, durantes os meses úmidos de março a setembro". O naturalista bávaro confirma os conhecimentos do prisioneiro político em meteorologia e deixa perceber que Bivar não era um preso comum, possuindo privilégios especiais, tratando não apenas com os da terra, mas com estrangeiros.

Ainda mais grave, o inconfidente Bivar possuía inumações minuciosas acerca de cada um dos principais agentes políticos, econômicos e culturais da segunda maior cidade portuguesa do Atlântico Sul. Esse conhecimento foi condensado, impresso e divulgado no Almanach para a Cidade da Bahia Anno 1812, publicado em fins de 1811 na Tipografia de Manoel Antonio da Silva Serva. Esse Almanaque foi possivelmente feito em colaboração com Ignacio José de Macedo. Foi Inocêncio Francisco da Silva, no Diccionário Bibliografico Portuguez (1860), quem ratificou a tradição em atribuir a Bivar a autoria do Almanaque. Isso pode ser confirmado por meio de uma observação feita por Miguel Calmon Du Pin e Almeida, encontrada no Jornal da Sociedade de Agricultura em 1836, no qual o Marquês de Abrantes observa que "para dar alguma idèa do nosso progresso nos varios ramos da producção, tratarei de comparar a presumida exportação de 10 mil contos, verificada agora, com a que se realisou no anno de 1810, constante do Almanack da Bahia, redigido pelo Sr. Bivar, à vista de Documentos authenticos, que o illustre Governador Conde dos Arcos lhe mandara franquear". "42 A ligação entre o Conde dos Arcos e Bivar é confirmada também por José Silvestre Ribeiro. Esse historiador recebeu, por volta de 1870, alguns apontamentos biográficos de Bivar, enviados pelo médico Francisco Antonio Rodrigues Gusmão, onde se diz que "chegado á Bahia, na embarcação que o levava degredado, o conde dos Arcos, então ali governador, se responsabilizou por elle, porque era muito seu amigo, e com muito empenho sollicitou para a corte do Rio de Janeiro, que ficasse ali o degredado". 43 Como pode a maior autoridade política da Capitania da Bahia mandar franquear documentos de natureza estratégica e econômica para um preso político?

A amizade entre D. Marcos de Noronha e Brito e o inconfidente é bastante improvável. O nobre português era 14 anos mais velho do que Bivar e não há registro de que tenham convivido ainda em Portugal. O Conde dos Arcos chegou ao Brasil no cargo de Governador do Pará em 1803, aos 32 anos,

\footnotetext{
${ }^{42}$ Jornal da Sociedade de Agricultura. Bahia, 31 de janeiro de 1836, transcrito pela revista em fevereiro. Agradeço a gentileza de Nelson Varon Cadena que encontrou e compartilhou essa informação.

${ }^{43}$ RIBEIRO, José Silvestre. Historia dos Estabelecimentos Scientificos, Litterarios e Artisticos de Portugal nos sucessisvos reinados da Monarchia. Lisboa, Typographia da Academia Real das Sciencias, Tomo IV, 1874, p.134
} 
quando Bivar era apenas um promissor jovem português que contava 17 para 18 anos. A afinidade e proteção de Arcos para com Bivar só podem ser explicadas dentro da sociabilidade maçônica e da oculta influência desse grupo na Capitania da Bahia. Sir James Prior, em novembro de 1813, registrou a presença de três lojas maçônicas em Salvador, demonstrando surpresa como a maçonaria era admirada e frequentada naquela cidade, apesar da perseguição que sofria nos países católicos. Prior revelou ainda que "there are here three lodges of the society, wich boast among their members the governor, archbishop, and the majority of the principal people, who do not, however, publicly own it; several of the minor clergy have been lately initiated". "Suas observações estão corretas, pois existiam as lojas Virtude e Razão, Humanidade e União. Prior afirmou ainda que o Conde dos Arcos e o Arcebispo D. José de Santa Escolástica Alvarez Pereira (1804-1813), assim como boa parte do clero, eram iniciados na maçonaria. Não bastasse o depoimento do viajante inglês, é reconhecido que o Conde dos Arcos hospedava em sua casa o mineiro José Eloy Ottoni, autor da primeira obra de natureza maçônica impressa no Brasil, a Parafraze dos Proverbios de Salomão (1815). ${ }^{45}$

Em carta a D. Fernando José de Portugal, o Marquês de Aguiar, a 1 de fevereiro de 1814, o Conde dos Arcos elogia os escritos de Bivar, sem identificar quais, e afirmar que não o mandou para o Rio Sena simplesmente porque os navios que partiam para Moçambique estavam cheios. Em um trecho da carta, o Conde dos Arcos revelou que

Nunca vi este homem, ninguém mo recommendou, ignoro qual seja seu Crime, sei q.' hé mui môço porque vi sua Certidão de idade, e conheço por seus escritos q.' hé dotado de talentos transcendentes; Não tenho a menor duvida de confessar a Augusta Prezença de Sua Alteza Real q.' me corta o coração a infeliz sorte de hum môço assim hábil, nem mesmo occulto agora q.' me tem sido summamente agradável podello conservar aqui sem ter faltado a meu dever pois q.' a verdadeira razão porque elle não tem partido hé porque nas occasioens que se tem aprezentado tem tido o numero cheio dos que cabem e podem ser transportados. ${ }^{46}$

\footnotetext{
${ }^{44}$ PRIOR, James. Voyage Along the Eastern Coast of Africa: To Mosambique, Johanna, and Quiloa and St. Helena; to Rio de Janeiro, Bahia, and Pernambuco in Brazil. In the Nisus frigate. London: Sir Richard Phillips and Co., p. 104-105.

${ }^{45}$ IGLESIAS MAGALHÃES, P.A. . "A Parafraze dos Proverbios de Salomão: O código moral dos pedreiros livres impresso na Bahia em 1815”. Revista Portuguesa de História do Livro, Lisboa, 2015, pp. 369-419.

${ }^{46}$ BNRJ. Coleção: Documentos biográficos. C-0877,043, n. ${ }^{\circ}$ 007. Conde dos Arcos, 1 de fevereiro de 1814.
} 
Difícil crer que o inconfidente não foi despachado para a África porque os navios partiam lotados. A proteção a Bivar tem razões políticas ocultas e está estampada no frontispício da revista As Variedades (1812, reeditada em 1814),

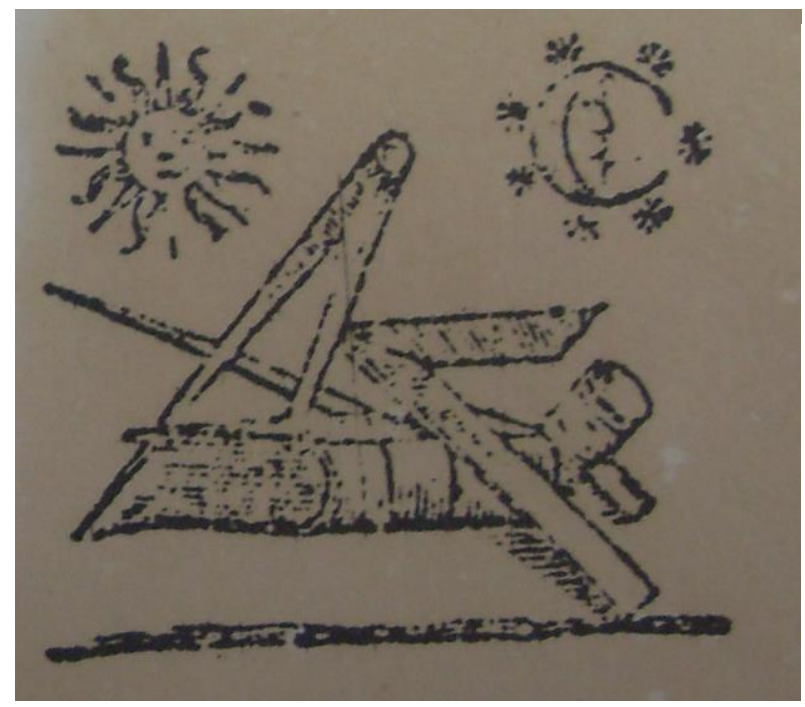

Insígnias maçônicas em detalhe do frontispício de As Variedades (1812)

a primeira que então se publicou no Brasil, sob diligência do próprio Bivar e, possivelmente, com a colaboração de Ignacio José de Macedo:

Bivar deixou pistas para indicar que ele era um dos redatores do referido periódico. O artigo "Sobre a Felicidade Doméstica" é, certamente, da sua autoria. Estava se relacionando com a jovem Violante Lima e, no final do artigo, registrou a seguinte mensagem:

Que digo eu, do fundo mesmo do carcere, ou da sepultura, o homem de bem exerce seu poder sobre outros homens. A injustiça ea calumnia que o arrastem á masmorra não alternão seu socego: ter-se-ha por livre na prizão, por isso que a sua consciencia não o accusa, e a opinião dos seus amigos, e dos homens bemfazejos, e sãos o consolará no meio dos maiores tormentos; e ele se dirá asi mesmo $=$ Nem todos me ultrajarão, alguns haverá que me fação justiça, e que se compadeçam da desgraça. = Finalmente , a sua sepultura será banhada pelas lágrimas sinceras de sua mulher, de seus filhos, e de seus amigos, e concidadãos.

Decerto Diogo Soares da Silva de Bivar teve grande presença intelectual na Tipografia de Serva, possibilitada por suas conexões junto à maçonaria local, inclusive também por sua proximidade com José Francisco Cardoso de Moraes e Ignacio José de Macedo. Há notícias de que, mesmo preso, continuou a escrever

\footnotetext{
47 "Sobre a felicidade doméstica". As Variedades ou Ensaios de Literatura. Bahia: Na Typographia de Manoel Antonio da Silva Serva, 1814, pp. 14-15.
} 


\section{e publicar textos, tendo seu talento reconhecido por conta deles. No prefácio da edição bahiense da Atala, o anônimo tradutor registrou que}

Não foi a ambição de gloria que me forçou a emprehender a presesente Traducção. A certeza em que sempre viví de que o homem se deve todo á Sociedade, foi o calor vivificante, que animando minhas débeis forças, me impelio a roubar algum tempo á minhas mais essenciais obrigações para me occupar a transmittir-te em linguagem Portugueza $=$ Os Amores de dois Selvagens nos Desertos Americanos = Obra do delicado pincel do sentimental Chateaubriand. O nome deste celebre Escriptor he bastante para tomares huma grande idéa da obra original; e quanto ao merecimento da versão, sem repunancia (sic), confesso conhecer eu que não devia manchar o delicado, e sublime dos pensamentos deste grande homem com o tosco, e grosseiro de minhas pequenas luzes neste genero de literatura: devo com tudo prottestar-te, que me esforcei quanto pude em conservar a mesma simplicidade, e belleza de estylo, que Chateaubriand com toda a destreza soube espalhar em toda sua obra. Accolhe, pois benigno, estes primeiros adejos de meu espirito como hum seguro penhor dos desejos que me animão para ser te util.

A Biblioteca Nacional do Rio de Janeiro conserva um conjunto de dezessete documentos manuscritos que permitem reconstruir a vida de Bivar ao tempo em que ele esteve preso na Bahia. O primeiro é o requerimento encaminhado ao Ministério do Império, suplicando que seja comutada sua pena de degredo para Rio de Serra, em permanência no Brasil; solicita ser perdoado, posto em liberdade e reabilitado em seus direitos e suas honras

Senhor. Aos Reaes Pez de Vossa Mag.e vem de novo prostrar-se Diogo Soares da Silva e Bivar amparado pelo Real Decreto de 6 de Fevereiro de 1818, pelo qual foi V. Mag.de Servido de commutar-lhe para a Capitania da Bahia o degredo a q.' em Portugal fôra condennado para o R.o de Senna; se as estupendas desventuras, e longos soffrimentos p. que na flôr dos seus annos passava o Supp.e com mais de 9 annos de carcere commoverão o Piedozo Coração de V. Mag.de para lhe indultar aquella Graça ouza o Supp.e esperar tão bem que a exemplaridade do seu procedim.to, os testemunhos da sua lealdade, e o amor pela Real Pessôa de V. Mag.de, e por a gloria e prosperidade do Estado, e da Nação, a cujo prol tem votado seus fracos talentos, tocarão de novo o Excelsso, e Beneficientifsimo Animo de V. Mag. para lhe fazer a Mercê de Haver por extincta, e cumprida a referida commutação restituindo o Supp.e ao pleno gozo da sua liberdade.

A Bondade, e Clemencia de V. Mag.de manifestos por tantos actos do seu Filicissimo Governo, e o sentim.to da propria consciencia do Supp.e na adoração que sempre prestou à Real Pessôa de V. Mag.de não deixão lugar a duvidar o Supp.e de que V. Mag.de se Dignará Attendê-lo compassivam.te em esta sua humilde supplica para lhe Fazer a Graça de asestituir a plenitude da sua liberdade, e a consideração que merece sempre pela nobreza, e decencia da sua fam.a, e pela de sua própria pessoa que em 
Crimes proprios da mocid.e, e das conjecturas imperiozas de dificeis tempos arrastarão a tamanhos infortunios.

Rezignado inteiramente na Bondade de V. Mag.de, e no Imperio daquella Real e Soberana Grandeza, que tem resolvido infelices os dias da desgraça de muitos afoita-se o Supp.e a esperar a mesma sorte, e por isso outra vez prostrado ante Throno Augusto de V. Mag.de. P. a V. Mag.de Seja Servido em Commutação do Glorioso Dia Natalicio do Principe Real, e por effeitos de Sua Real Clemencia, e Piedade, Fazer-lhe a Graça que humildemente implora. E. R. M.48

Em 1816, acompanhando o requerimento supra, Bivar escrevera uma carta ao Príncipe Regente, suplicando a restituição da sua liberdade e a absolvição da pena de degredo. No documento, revela que sustentava a sua família por meio dos seus escritos. Segue o texto na íntegra:

Diz Diogo Soares da Silva e Bivar, prezo no Forte de S. Pedro na Cidade da Bahia, que tendo encaminhado à Augusta Presença de V. A. R., sua humilde suplica para ser restituido à sua liberdade, e absolvido do degredo a que está condennado, Houve por bem V. A. R. de Mandar por Aviso Regio de 18 de Agosto do presente ano, que informasse o Conde Governador da Bahia; e subindo esta informação à Augusta Presença de V. A. R., por posterior Resolução, Foi V. A. R. Servido Mandar que sobre o Requerimento do Sup.e informarem os Governadores de Portugal para o que se tem expedido o respectivo Aviso. E porque esta segunda Informação em razão da longinqua distancia em que se axão os Informantes, ha de demorar-se tempo dilatado, antes que possa ver prezente a V. A. R., no entanto que o Sup. ${ }^{e}$ continua a gemer agrilhoado em prizão, em que diariamente deteriora a sua saúde desfalecida a ponto, que já não esperanças restabelecimento, como o Sup. e já fez certo a V. A. R. por Documentos authenticos que existem na Secretaria de Estado dos Negocios do Brazil, e sobre o q. já igualmente informou o sobredito Conde Governador, e novamente o atesta o

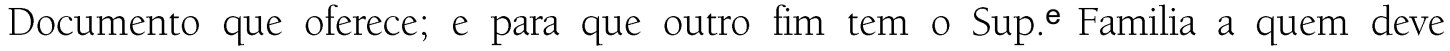
sustentar, portanto humildemente recorre o Sup.e á Soberana Clemencia, e Munificente Piedade de V. A. R., suplicando a V. A. R. de Conceder-lhe homenagem de muro a dentro da dita Cidade da Bahia, até final Decizão em contrario de V. A. R.

Senhor! O Sup. ${ }^{e}$ padece trabalhoza prizão ha seis anos: quando apenas contava 20 perdeo com a liberdade, avultados bens, e tudo perdeo! V. A. R. não ha de permitir pois que o seu castigo seja eterno, já que foi desmedido, ou que não tenha alivio senão, quando morto! Com os trabalhos da sua pena tem ele até agora sustentado sua triste Familia; mas o afinco desses mesmos trabalhos, unidos aos incômodos, e sofrimentos do Carcere, tem-lhe adquirido molestias, que prestes o privavão do unico recurso q. lhe resta p.a subsistir, se a Piedade de V. A. R. lhe não acudir e valer Soberanamente. Sem saúde e sem liberdade até onde irão os infortunios, e a mizeria do Sup. ? Senhor! the não tem forças p. ${ }^{a}$ tantos martyrios, nem crimes que os mereção! Outra vez o jura na Augusta Prezença de V. A. R., e o jurará na Prezença do Eterno cuja Infinita Bondade V.

${ }^{48}$ BNRJ. Coleção: Documentos biográficos. C-0877,043 n009, Diogo Soares da Silva de Bivar. S.l / s.d. 
A. R. imita tratando aos seus vafsalos com a mesma indulgencia e bondade com que Ele trata as suas Creaturas. V. A. R. que se Dignou de receber compasivo a primeira Suplica que este infeliz encaminhou ao Throno de V. A. R., Digne-se de Aceitar esta com a mesma Compaixão, e de Conceder-lhe a Graça da Homenagem que suplico para salvar os definhados restos de sua mízera existencia, não duvidando o Sup. ${ }^{e}$ de afignar termo e de prestar idoneos Fiadores à Homenagem. Senhor!

Pede a V. A. R.

Graças e Piedade!

Diogo Soares da Silva e Bivar. ${ }^{49}$

Bivar teve, supostamente, a saúde fragilizada pelo cárcere já no início de 1812 e no ano seguinte uma junta médica foi formada para emitir um parecer sobre o seu estado. Essa junta foi encabeçada pelo médico Manoel José Estrella, lente da Cadeira Régia de Cirurgia., que cuidou e curou, segundo atesta, o prisioneiro enfermo. É surpreendente o zelo que o governo teve com esse prisioneiro inconfidente. Aliás, é bem possível, que, como quase todos os autores que publicaram na Tipografia de Serva e parte dos professores da Escola de Cirurgia da Bahia, Estrella também fosse pedreiro-livre.

Manoel Jozé Estrella, Professo na Ordem de Christo, lente da Cadeira Regia de Cirurgia, e Delegado do Conselheiro Cirurgião Môr do Reino em toda a Capitania da Ba por S. Alteza Real, Que D.s g.e. Attesto com juramento, que Diogo de Bivar padeceo no principio do preterito anno de 1812 hua febre nervosa, assas grave, acompanhada de frequentes delinquios, da qual felism. ${ }^{\mathrm{e}}$ se pode restabelecer mediante os potentes, e energicos remedios, $\mathrm{q}^{\prime}$. The administrei, ficando sujeito a vapores, ou esparmos, tristeza continuada d'animo, malicez, e m. ${ }^{\text {to }}$ abatido, precizado por isso de exercicio perenne de cavalo, mudansa d'ares, e outros meios salutares, de que não pode gozar na habitação em que se acha; e como disso me pede hum docum..$^{\text {to }}$ em qualidade de seu assitente, em obsequio á verdade lhe dou fe. Ba 24 de M.o de 1813. Manoel Jozé Estrella

Outros médicos, complementando o diagnóstico do doutor Estrella, assistiram à saúde de Bivar, à exemplo de José Ramos d'Aragão, do Real Hospital Militar, que emitiu seu parecer, um mês depois, alegando que o prisioneiro "se acha em sumo abatimento, em conceq. ' d'uma emfermid. ' de nervos q.' padece, e q.' por conseguir alivios preciza d'um const. ${ }^{e}$, mas moderado exercicio em Ar Livre". O médico José Manoel Antunes confirmou que "a sua infermidade foi huma febre nervosa, acompanhada de frequentes delinquios, da qual se pode restabelecer, ficando sujeito a [...] huma melancolia profunda, e continuada, palides, e muito abatimento; he portanto que se lhe fas muinto precizo o

\footnotetext{
${ }^{49}$ BNRJ. Coleção: Documentos biográiicos. C-0877,043 n004, Diogo Soares da Silva de Bivar. S.l / s.d.

${ }^{50}$ BNRJ. Coleção: Documentos biográficos. C-0877,043 nº13, Manoel José Estrella. Bahia, 24 de março de 1813.
} 
exercicio de Cavalo, respirar outro Ar". Cristovão Pessoa da Silva, Cirurgião-mor da Artilharia, afirmou que Bivar "tem sido por t $^{\text {tas }}$ vezes acometido de insultos nervosos, a ponto de perder os sentidos, e entrar em acidentes convulços, ou Epileticos". Por fim, o cirurgião José Alvares do Amaral definiu o quadro de saúde de Bivar como

huma febre nervosa sobremaneira grave, infelismente labora ainda, por continuar as mesmas cauzas, que a ella o levarão, debaixo de symptomas esparmicos, fraqueza de entranhas, asthenia geral, e declinação de vida, e apesar de remedios energicos, de que assiduamente tem uzado, não tem podido restabelecer-se, e não o poderá fazer sem o uzo da equitação, ${ }^{51}$

No âmbito jurídico, a junta médica que examinou Bivar foi reconhecida pelo Doutor Antonio José Osório de Pina Leitão, cavaleiro da Ordem de Cristo e desembargador no Tribunal da Relação da Bahia. O fato é que Bivar curou-se das suas enfermidades. Tão bem curado que se enamorou da jovem bahiense Violante de Lima Bivar, órfã de pai. O casamento foi realizado por seu procurador, o coronel José Thomas Boccacciari, e celebrado pelo vigário da freguesia de Nossa Senhora da Vitória, Antonio de Souza (que viria a ser Deputado nas cortes de Lisboa), ambos, muito possivelmente, membros do influente grupo que José da Silva Lisboa denominou como a Cabala Maçônica da Bahia.

Curiosamente, mesmo com a saúde tão debilitada, Bivar teve disposição para fazer três filhos entre 1812 e 1817. Logo, do casamento com Violante de Lima, nasceram Rodrigo Soares Cid de Bivar, Luís Garcia Soares de Bivar e Violante Atabalipa Ximenes de Bivar e Velasco. É notável que Bivar tenha inoculado nos seus filhos o gosto pelos livros e pelas traduções. Violante Atabalipa, nascida em 1817 na freguesia de Nossa Senhora da Vitória, em Salvador, tornou-se uma das mais, se não a mais, influente jornalista brasileira no século XIX. Seguindo os passos do pai, tornou-se eximia tradutora, vertendo para o português o Chale de Cachemira Verde, de Alexandre Dumas. ${ }^{52}$ Exatos 40 anos depois da impressão bahiense da Atala, em 1859, D. Violante publicou

\footnotetext{
${ }^{51}$ Idem. C-0877,043 n014; C-0877,043 nº15; C-0877,043 n016; C-0877,043 nº17.

52 DUMAS, Alexandre. O Chale de cachemira verde; comedia de Alexandre Dumas e Eugenio Nus / traduzida do francês... [por] Violante Atabalipa Ximenes de Bivar e Vellasco. Rio de Janeiro: Typ. e Livraria de B. X.P. de Sousa, [1857]. [1] f., 48 p., [1] f. O Chale de cachemira foi encaminhado para censura no Conservatório Dramático a 27 de novembro de 1857, diante do qual Diogo Soares da Silva de Bivar declarou que "Sendo a impetrante e traductora minha filha, julgo me impedido p. a deferir", encaminhando-o para Antonio Felix Martins interpor o juízo. BNRJ. Coleção: Conservatório Dramático Brasileiro I-08,14,062

< http://objdigital.bn.br/objdigital2/acervo_digital/div_manuscritos/mssl453045/mss1453045.pdf >. Acesso em: 16 de maio de 2017.
} 
no Rio de Janeiro Algumas Traduções das Línguas Franceza, Italiana e Ingleza. ${ }^{53}$ Violante, em homenagem ao seu pai, dedicou-lhe a tradução de O orphão, pequeno extracto das obras do venerado padre John Tood, vertido da lingua inglesa.

Retomando a questão da autoria anônima da tradução da Atala, é necessário recapitular e sintetizar os fatos possíveis de se estabelecer: 1- Desde a fundação da Sociedade Tubuciana em 1801, o secretário Bivar e seus pares instituíram um programa de traduções de obras estrangeiras, com destaque para literatura; 2- A primeira tradução da Atala em 1810, proibida de circular em Portugal desde 1812, foi executada por Filippe Ferreira de Araújo e Castro, amigo e confrade de Bivar na Sociedade Tubucciana. 3- Bivar, preso na Bahia desde 1810, participou ativamente dos projetos editoriais da Tipografia de Manoel Antonio da Silva Serva e a, partir de 1811, atuou como colaborador de a Idade d'Ouro do Brazil, de As Variedades (1812) e do Almanaque de 1812, sempre se mantendo no anonimato; 3- Bivar conhecia com esmero a língua francesa e sua pronúncia, já tendo publicado, anonimamente, o Compendio de Língua Francesa (1811); 4- Bivar estava ligado, por sociabilidades ocultas, ao Conde dos Arcos, que lhe remetera documentos do governo ainda preso e foi o responsável por encaminhar ao censor José Francisco Cardoso de Moraes o manuscrito da Atala em 1817; 5- Na carta de 1816, Bivar revela "com os trabalhos da sua pena tem ele até agora sustentado sua triste Familia", confirmando que manteve contínua atividade como escritor/tradutor; 6- Ainda preso, em 1819, Bivar precisava manter-se protegido pelo anonimato; 7- Era pedreiro-livre, possivelmente associado com outros autores/editores que atuavam junto à Tipografia de Serva, à exemplo de Ignacio José de Macedo, José Francisco Cardoso de Moraes e José Eloy Ottoni, o que lhe facultava a possibilidade de agir dentro de uma sociedade iniciática, que protegia, discretamente, os seus confrades; 8- Seus filhos Violante Ataliba e Luis Garcia Soares de Bivar, seguindo o exemplo do pai, também se tornaram tradutores de novelas; 8 - $O$ estilo e a linguagem sofisticada empregada na tradução bahiense da Atala se alinham aos demais escritos identificados como da autoria de Bivar. A convergência dos postulados acima confirma Diogo Soares da Silva Bivar como o tradutor da edição bahiense da Atala.

Bivar só foi isentado do crime de inconfidência por decreto de D. João VI, de 26 de março de 1821, quando foi restituído à sua liberdade com todos os

\footnotetext{
${ }^{53}$ VELASCO, Violante Atabalipa Ximenes de Bivar. Algumas Traduções das Línguas Franceza, Italiana e Ingleza. Rio de Janeiro : Tip. de Bernardo Xavier Pinto de Sousa, 1859. [2 fls.], IV, 131, [1], 114, 11, 4 p. 1.
} 
seus direitos, honras e prerrogativas. Seis meses depois, a 21 de setembro de 1821, foram publicadas as novas disposições para a aplicação da censura de impressos em Portugal e no Império ultramarino, determinadas pelo então Ministro e Secretário de Estado dos Negócios do Reino Fillipe Ferreira de Araújo e Castro (ele mesmo, o primeiro tradutor da Atala, que em 1812 fora censurada). ${ }^{54} \mathrm{Na}$ Bahia, a 19 de fevereiro de 1822, a Junta Governativa acatou as determinações do governo de Lisboa e nomeou para a Comissão de Censura Diogo Soares da Silva e Bivar, ao lado de dois desembargadores, Francisco Carneiro de Campos e Joaquim Ignacio Silveira da Motta. ${ }^{55}$ Ainda na Bahia, exerceu a advocacia, mudando-se depois para o Rio de Janeiro, onde anunciou seus serviços:

Diogo Soares da Silva de Bivar Advogado bem conhecido no Brazil achando-se de presente nesta Capital incumbido de importantes negocios da Praça da Bahia, tem a honra de offerecer seus serviços ao mui digno e respeitavel Publico desta Capital e Provincia, podendo procuralo todas as pessoas que se quizerem servir de seus limitados conhecimentos na rua da Misericordia na caza N. ${ }^{0} 106$, desde as horas da manhã em todos os dias. ${ }^{56}$

De quais "importantes negócios" estava incumbido, e por quem, permanece um mistério. Uma pista pode estar no Diário de Notícias, que questiona o "Porque não vem huma reprezentação do Rio de Janeiro, onde Bivar, e Biancardi tem, por ordem da mesma facção, instigado os ânimos com os receios da colonização?" 57 Alguns anos depois, na Corte, Bivar ascendeu socialmente e mudou-se para a rua da Ajuda, casa n.100. ${ }^{58}$ periódico $O$ Espelho, dirigido e redigido pelo matemático Manoel Ferreira de Araújo Guimarães afirma que Bivar chegou, no Rio de Janeiro, a ser proposto por Gonçalves Ledo, proeminente pedreiro-livre fluminense, para o cargo de Secretário de Estado do Império.

A isto, Sr. Malagueta, chamo eu sentimentos constitucionaes, e não aos d'aquelle, que dizem, governão a sua familia constitucionalmente. Vossa Reverendissima Secretarial attribue-lhe no papel, que disse hia a publicar, medidas despóticas, como por exemplo a sahida de Ledo \& C. ', não lembrando que o mesmo lhe poderia accontecer se o bom Povo do Rio de Janeiro requeresse a S.M.I para e mandar a elle tambem na sucia, e ao

\footnotetext{
${ }^{54}$ Gazeta de Lisboa, n. 299, Sábado, 23 de setembro de 1820, p. 5.

${ }_{55}$ Idade d'Ouro do Brazil, n. 22, Sábado, 24 de fevereiro de 1821, pp. 2-3.

${ }^{56}$ Diário do Rio de Janeiro, n. 9, Quinta-feira, 11 de julho 1821, p.70.

${ }_{57}^{57}$ Correio do Rio de Janeiro, n. 41, Quarta-feira, 29 de maio de 1822, p. 167.

${ }^{58}$ Diario do Rio de Janeiro, n. 20, Quinta-feira 28 de junho de 1827, p. 79.
} 
seu amigo Bivar, a quem quiz metter à cara para ser Secretario d'Estado, dizendo a todas aquellas pessoas, que podião fallar mais de perto ao Imperador, creio que por se não lembrar já que a pelle, que possuia em tal parte, não he a mesma que agora tem depois da sahida de Junot, visto ter levado huma formidavel roda de açoites no pelourinho em Lisboa, como foi publico por traidor da Nação, como o póde provar a Cidade inteira, os quaes produzião o grande milagre das carnes mortas passarem a carnes vivas, e o Sr. Malagueta he intimo amigo d'elle, como de todos os marotos, nem por isso se lhe podendo applicar o ditado - dize-me com quem vives, dir-te-hei as manhas que tens porque ellas já erão anteriores á intima amizade Bivaresca. ${ }^{59}$

Sua contribuição para o desenvolvimento cultural da Corte após a consolidação da independência foi inestimável, mas permanece ignorada. Foi sócio fundador do Instituto Histórico e Geográfico Brasileiro (IHGB) e, a partir de 1843, presidente do Conservatório Dramático Brasileiro. Bivar, após a independência, continuou sua carreira de censor de escritos históricos e literários, tanto no IHGB quanto no Conservatório. ${ }^{60}$ Ainda com todos os encargos e o reconhecimento dos seus pares, continuou sendo um personagem discreto.

Em 1853, aos 68 anos, Bivar ficou viúvo de dona Violante de Lima Bivar. Vieram os netos e Luiz Garcia Soares de Bivar batizou seu filho com o mesmo nome do seu pai. Diogo Soares da Silva e Bivar faleceu às 20:15 da noite de 11 de outubro de 1865, aos 80 anos. Sua morte foi causada por "amollecimento cerebral" ou acidente vascular cerebral hemorrágico. Seu necrológio o indicou como "brasileiro", visto que viveu no país durante três quartos da sua vida. ${ }^{61}$

Joaquim Manoel de Macedo fez a elegia fúnebre de Bivar no IHGB. O ilustre orador, contudo, silenciou a respeito das suas obras, então bastante raras e difíceis de encontrar. ${ }^{62}$ Em 1865, quando Macedo proferiu seu discurso, já se contavam mais de 60 anos desde que Bivar publicara seus primeiros trabalhos em Portugal e mais de 50 anos desde que publicou anonimamente seus textos pela Tipografia de Manoel Antonio das Silva Serva, que não devem ter tido mais do que 200 ou 300 exemplares. Identificar a obra anônima de Bivar é necessário para resgatar não apenas a biografia de um dos agentes culturais mais atuantes

\footnotetext{
${ }^{59}$ O Espelho, n. 120, Rio de Janeiro, Sexta-feira, 10 de janeiro de 1823. O Espelho, redigido pelo português Luis Augusto May, durante 1822 e início de 1823, publicou os mais agressivos artigos contra o jornal A Malagueta e contra o grupo maçônico de Gonçalves Ledo, do qual Bivar faria parte.

${ }^{60}$ LEMOS, Valéria Ponto (org.). Os exames censórios do Conservatório Dramático Brasileiro: inventário analítico. Rio de Janeiro: Fundação Biblioteca Nacional, 2014. Bivar foi o mais influente censor do Conservatório e este catálogo indica centenas de obras em português e francês por ele censurada.

${ }_{62}$ Correio Mercantil, n. 281, Domingo 15 de outubro de 1865, p. 2

${ }^{62}$ MECEDO, Joaquim Manoel de. "Elogio histórico do Conselheiro Diogo Soares da Silva de Bivar (15 de dezembro de 1865)". Revista do Instituto Histórico e Geográfico, T. 28, Rio de Janeiro, p. 344-347.
} 
na Bahia, mas também as histórias da imprensa e da literatura na referida capitania em fins do período colonial.

As traduções da Atalá tiveram o mérito de reunir, em Portugal, na Inglaterra e no Brasil, três indivíduos que fizeram das suas biografias instrumento de oposição ao Antigo Regime. Araújo e Castro, um dos expoentes da Revolução Constitucional de 1820; Hipólito da Costa, que antes de falecer em 1823, já era reconhecido como um dos homens mais influentes no processo de Independência do Brasil, e por fim, o inconfidente Bivar. Este último, um jovem português, prisioneiro no forte de São Pedro em Salvador, que anonimamente usou a palavra impressa para influenciar o pensamento de gerações de escritores e intelectuais brasileiros ao longo do século XIX. As letras desses três homens floresceram nas sombras da censura, do exílio e da cadeia. À luz da História, pode-se agora conhecer melhor uma parte dos significados da literatura que esses indivíduos usaram como arma contra o autoritarismo do Antigo Regime.

Recebido em 02/05/2016

Aprovado em 08/05/2017 